\title{
Review Article \\ Dendritic Cell-Based Approaches for Therapeutic Immune Regulation in Solid-Organ Transplantation
}

\author{
Giuseppe Vassalli ${ }^{1,2}$ \\ ${ }^{1}$ Department of Cardiology, Centre Hospitalier Universitaire Vaudois, 1011 Lausanne, Switzerland \\ ${ }^{2}$ Molecular Cardiology Laboratory, Fondazione Cardiocentro Ticino, 6900 Lugano, Switzerland \\ Correspondence should be addressed to Giuseppe Vassalli; giuseppe.vassalli@cardiocentro.org
}

Received 31 May 2013; Accepted 16 September 2013

Academic Editor: F. H. J. Claas

Copyright (c) 2013 Giuseppe Vassalli. This is an open access article distributed under the Creative Commons Attribution License, which permits unrestricted use, distribution, and reproduction in any medium, provided the original work is properly cited.

\begin{abstract}
To avoid immune rejection, allograft recipients require drug-based immunosuppression, which has significant toxicity. An emerging approach is adoptive transfer of immunoregulatory cells. While mature dendritic cells (DCs) present donor antigen to the immune system, triggering rejection, regulatory DCs interact with regulatory $\mathrm{T}$ cells to promote immune tolerance. Intravenous injection of immature DCs of either donor or host origin at the time of transplantation have prolonged allograft survival in solid-organ transplant models. DCs can be treated with pharmacological agents before injection, which may attenuate their maturation in vivo. Recent data suggest that injected immunosuppressive DCs may inhibit allograft rejection, not by themselves, but through conventional DCs of the host. Genetically engineered DCs have also been tested. Two clinical trials in type-1 diabetes and rheumatoid arthritis have been carried out, and other trials, including one trial in kidney transplantation, are in progress or are imminent.
\end{abstract}

\section{Introduction}

Allogeneic cell and solid-organ grafts trigger immune responses that cause destructive graft rejection in the absence of sustained drug-based immunosuppression [1]. Unfortunately, the latter is associated with major side effects including severe infections and cancer, especially after many years of treatment. Moreover, immunosuppressive drugs have failed to prevent chronic graft rejection, which is primarily manifested by allograft vasculopathy. The hope in the immunotherapy field is to develop a therapy that targets and neutralizes the alloimmune response selectively, while leaving protective immunity intact.

Patients with a functioning allograft in the absence of maintenance immunosuppression have been described occasionally [2]. In some of them, immunosuppressive drugs were discontinued because of infection or cancer [3]. Others decided to stop taking the drugs [4]. Some liver transplant recipients were enrolled in studies of weaning immunosuppression [5]. Moreover, some kidney transplant recipients participated in studies of tolerance induction [6-9] which, in part, included hematopoietic cell transplantation $[8,9]$. These reports demonstrate the sporadic occurrence of operational tolerance, as defined by lack of destructive graft rejection in the absence of maintenance immunosuppression [10].

Sixty years ago, Billingham et al. described "actively acquired tolerance" of foreign cells. They claimed that, "if the first presentation of foreign cells takes place in fetal life, resistance to a graft [from the same donor or from some other member of the donor's strain] transplanted on some later occasion is abolished or at least reduced" [11]. This concept implied the existence of regulatory mechanisms, other than deletion of donor-reactive immune cells, favoring graft acceptance. Thirty years later, Hall et al. reported that rats that accepted cardiac allografts for extended periods of time in the absence of treatment with cyclosporine or other immunosuppressive drugs had suppressor $\mathrm{T}$ cells that actively prevented graft rejection [12].

Multiple leukocyte populations including dendritic cells (DCs), macrophages, T and B cells, and natural killer (NK) cells participate in the immune reaction against the allograft [1]. However, these populations include subsets of cells showing regulatory activity. Analyses of immune cells in patients who did not reject the allograft in the absence 
of drug-based immunosuppression revealed major roles for regulatory $\mathrm{T}$ cells (Tregs) [13-15], regulatory $\mathrm{B}$ cells [1618 ], and regulatory DCs in the establishment of operational tolerance. Regulatory immune cells are selected to either exert inhibitory functions during development or acquire regulatory activity within the graft or in draining lymphoid tissue [2]. The balance between donor-reactive effector cells and regulatory cells in the graft and its environment is naturally shifted towards effector cells and graft rejection. In this review, we wish to summarize our current understanding of tolerogenic DCs favoring the development of antigenspecific immune tolerance and graft acceptance (Table 1). Emerging DC-based approaches for therapeutic immune modulation in solid-organ transplantation, with a focus on heart transplantation, are briefly discussed.

\section{DC Populations}

DC and monocyte lineages originate from a common monocyte and DC progenitor (MDP) that gives rise to monocytes and committed DC progenitors (CDPs) in the bone marrow. CDPs then give rise to pre-DCs that migrate to lymphoid and nonlymphoid tissue and differentiate into the two major populations of lymphoid tissue DCs and nonlymphoid tissue $\mathrm{CD}_{103}{ }^{+}$DCs $[22,23,40]$. Acting as antigen-presenting cells, DCs trigger innate and adaptive immune responses to microbial antigens and alloantigens, as well as to selfantigens in autoimmune diseases. DCs initiate the innate immune response through activation of NK cells. They also set off the adaptive immune response through activation of naive $\mathrm{B}$ and $\mathrm{T}$ lymphocytes. Besides their traditional role as immunogenic cells, DCs regulate the immune reaction and mediate peripheral T-cell unresponsiveness under homeostatic conditions in vivo [41]. The regulatory activity of DCs can be accounted for by multiple mechanisms including the production and release of anti-inflammatory cytokines [32], Fas/Fas-ligand-induced apoptosis of effector immune cells [42], deletion, and induction of Tregs [39, 43-46] (Figure 1). Tolerogenic DCs comprise a majority of immature DCs and subpopulations of DCs with various maturation stages, including plasmacytoid DCs [43]. However, a major drawback in vivo is the potential of tolerogenic DCs to mature during infections or inflammation, which would convert them into immunogenic cells [47].

DCs are a heterogeneous population. At least seven DC subpopulations have been defined in mice based on differential expression of surface and intracellular markers [48-53]. The relationships between mouse and human DC populations are incompletely understood; however, recent comparative genomics studies have revealed functional equivalences between DC subsets in the two species [25]. Based on morphology, cell-surface markers, and gene expression profiles, DCs have traditionally been subdivided into classical and plasmacytoid DCs $[24,27,54-57]$. The latter are characterized by the CD11c ${ }^{\text {low }} \mathrm{CD} 45 \mathrm{RA}^{\text {hi }} \mathrm{MHC}-\mathrm{II}^{\text {low }}$ immunophenotype in mice and the $\mathrm{CD} 4{ }^{\text {hi }} \mathrm{CD} 8^{\text {neg }} \mathrm{CD} 11 \mathrm{c}^{\text {low }} \mathrm{CD} 45 \mathrm{RA}{ }^{\text {hi }} \mathrm{MHC}$ $\mathrm{II}^{\text {low }}$ immunophenotype in human [2].
Alternatively, a development-oriented nomenclature has also been used [23]. This classification subdivides DCs into conventional and monocyte-derived DCs. It is based on the assumption that monocytes give rise to mucosal DCs, but not to splenic, conventional DCs [58]. The existence of genuine monocyte-derived DCs in vivo is presently being explored. At steady state, most DCs in mouse lymphoid organs do not arise from monocytes and depend upon fms-like transcript 3 ligand (Flt3L) for their development [59]. However, some tissue (e.g., the gut) harbor macrophage colony-stimulating factor (M-CSF) - dependent monocytes at steady state [60, 61]. Langerhans cells are DCs within the epidermis and other squamous epithelia, which rely on M-CSF for their development $[60,62]$. In histiocytosis $X$, the expansion of Langerhans cells is manifested by either granuloma formation or a more diffuse proliferative disease [63].

Another classification subdivides DCs into resident and migratory DCs [23]. Resident DCs traffic directly to lymphoid tissue from a blood precursor, whereas migratory DCs first enter tissue before moving to lymph nodes [64-66]. DC populations express distinct pattern recognition receptors [67] and play different roles in nature. Monocyte-derived DCs can be observed in lymphoid tissue in response to infection with Leishmania major [68] or Listeria monocytogenes [69].

The development of DCs with either immunogenic or regulatory activity depends on a series of biological processes including differentiation, expansion, migration, antigen uptake and processing, and maturation.

\section{DC Maturation}

Under homeostatic conditions, tissue-resident DCs are immature and express low levels of major histocompatibility complex (MHC) class II and little or no T-cell costimulatory molecules. The role of immature DCs is not precisely defined, as they can give rise to either mature DCs or semimature regulatory DCs that share some phenotypic traits of mature DCs (e.g., CCR7 chemokine receptor expression [70]). Immature DCs sense the presence of pathogen- and damage-associated molecular patterns (PAMPs and DAMPs) from microbial agents and damaged cells, respectively, and activate proinflammatory molecular signaling cascades, such as nuclear factor kappa $\mathrm{B}(\mathrm{NF} \kappa \mathrm{B})$ and interferon responsive factor (IRF) pathways $[71,72]$. Activation of these signaling pathways is associated with DC maturation. Maturing DCs lose their ability to take up soluble antigen and acquire T-cell stimulatory activity as a result of increased antigen processing capacity and upregulation of $\mathrm{MHC}$, T-cell costimulatory molecules, and proinflammatory cytokines [73, 74]. Traffic molecules (e.g., CCR7) are upregulated in maturing DCs, allowing them to migrate to lymphoid tissue [70, 75-78]. In vitro, mature DCs present "probing movements" characterized by the incessant lengthening and retraction of long processes from the cell body [79]. Steady-state DCs in intact lymph nodes in vivo extend and retract processes in a fairly similar way [80]. Immature DCs and, to a lesser extent, mature DCs take up particles and apoptotic cells [81, 82]. Uptake 
TABLE 1: Recent advances in DC biology, tolerogenic DCs, and pharmacological conditioning protocols.

\begin{tabular}{|c|c|c|}
\hline & Authors & Reference \\
\hline \multicolumn{3}{|l|}{ Tolerogenic DCs } \\
\hline $\begin{array}{l}\text { Constitutive ablation of DCs breaks self-tolerance of } \mathrm{CD}^{+} \mathrm{T} \text { cells leading to fatal } \\
\text { autoimmunity }\end{array}$ & Ohnmacht et al. & [19] \\
\hline $\begin{array}{l}\text { Tolerogenic DCs favor graft tolerance through interferon- } \gamma \text { and Epstein-Barr virus-induced } \\
\text { gene } 3\end{array}$ & Hill et al. & {$[20]$} \\
\hline $\begin{array}{l}\text { Tolerogenic DCs generated with immunosuppressive cytokines induce antigen-specific anergy } \\
\text { and regulatory properties in memory } \mathrm{CD} 4^{+} \mathrm{T} \text { cells }\end{array}$ & Torres-Aguilar et al. & {$[21]$} \\
\hline \multicolumn{3}{|l|}{ DC genealogy } \\
\hline $\begin{array}{l}\text { DC and monocyte lineages originate from a common progenitor that gives rise to monocytes } \\
\text { and committed DC progenitors, which give rise to lymphoid tissue DCs and nonlymphoid } \\
\text { tissue DCs }\end{array}$ & Liu and Nussenzweig & {$[22]$} \\
\hline $\begin{array}{l}\text { DCs in mouse lymphoid organs in the steady state are monocyte independent and require Flt } 3 \mathrm{~L} \\
\text { for their development. Other tissue may contain additional M-CSF-dependent monocytes }\end{array}$ & $\begin{array}{l}\text { Steinman and } \\
\text { Idoyaga }\end{array}$ & [23] \\
\hline $\begin{array}{l}\text { The differing origins of gut DCs may explain how the intestinal immune system manages to } \\
\text { destroy harmful pathogens while tolerating beneficial bacteria }\end{array}$ & Laffont and Powrie & {$[24]$} \\
\hline Comparative genomics reveals functional equivalences between human and mouse DC subsets & Crozat et al. & [25] \\
\hline \multicolumn{3}{|l|}{ Plasmacytoid DCs (pDCs) } \\
\hline $\begin{array}{l}\text { Compared to conventional DCs, pDCs show reduced costimulatory molecule expression and } \\
\text { poor T-cell allostimulatory capacity. Under homeostatic conditions, nonlymphoid } \\
\text { tissue-resident pDCs regulate mucosal immunity and the development of both central and } \\
\text { peripheral tolerance }\end{array}$ & Rogers et al. & [26] \\
\hline $\begin{array}{l}\text { Human pDCs preferentially express immunoglobulin-like transcript } 7 \text { (ILT7), which activates } \\
\text { an immunoreceptor tyrosine-based activation motif- (ITAM-) mediated signaling pathway }\end{array}$ & Cao and Bover & {$[27]$} \\
\hline \multicolumn{3}{|l|}{ Pharmacological DC conditioning } \\
\hline $\begin{array}{l}\text { Rapamycin-conditioned, alloantigen-pulsed DCs present donor MHC class I-peptide via the } \\
\text { semidirect pathway and inhibit survival of antigen-specific } \operatorname{CD} 8^{(+)} \mathrm{T} \text { cells }\end{array}$ & $\begin{array}{l}\text { Thomson et al. and } \\
\text { Fischer et al. }\end{array}$ & {$[28,29]$} \\
\hline Human rapamycin-treated DCs are only partially maturation resistant in vivo & Macedo et al. & {$[30]$} \\
\hline Adenosine $\mathrm{A}_{2} \mathrm{AR}$ agonist-conditioned DCs attenuate acute renal ischemia-reperfusion injury & Li et al. & [31] \\
\hline Vitamin $\mathrm{D}_{3}$-conditioned DCs induce effector T-cell apoptosis and antigen-specific Tregs & Nikolic and Roep & [32] \\
\hline \multicolumn{3}{|l|}{ Role of conventional DCs of the recipient in tolerogenic DC therapy } \\
\hline Depleting recipient DCs at the time of tolerogenic DC therapy abrogates its beneficial effect & $\begin{array}{l}\text { Divito et al., } \\
\text { Wang et al. }\end{array}$ & {$[33,34]$} \\
\hline \multicolumn{3}{|l|}{ Role of exosomes } \\
\hline Exosomes mediate transfer of functional microRNAs between mouse DCs & Montecalvo et al. & {$[35]$} \\
\hline Exosomes from immature DCs plus rapamycin induce tolerance to mouse cardiac allografts & Li et al. & [36] \\
\hline \multicolumn{3}{|l|}{ Clinical studies of tolerogenic DCs } \\
\hline Phase- 1 trial of autologous tolerogenic DC therapy in patients with type- 1 diabetes & Giannoukakis et al. & {$[37]$} \\
\hline Clinical trials of tolerogenic DC therapy in patients with rheumatoid arthritis & Hilkens and Isaacs & [38] \\
\hline OneStudy phase-1 trial of autologous tolerogenic DC therapy after kidney transplantation & Moreau et al. & [39] \\
\hline
\end{tabular}

of apoptotic cells has been implicated in antigen crosspresentation, a mechanism that entails either immune tolerance under homeostatic conditions or immune activation upon DC maturation [83]. In addition, DCs participate in two "nonclassical" pathways of antigen presentation that involve autophagy of cytosolic components for presentation on MHC class II and cross-presentation of endocytosed substrates on MHC class I [84]. Peptide-MHC-class II complexes formed in lysosomes during DC maturation move to the cell surface [85-87] and interact with the T-cell receptor. Maturing DCs upregulate $\mathrm{T}$-cell costimulatory molecules including CD80, CD86, CD40, OX40L, and inducible T-cell costimulator ligand (ICOSL/CD275) $[88,89]$, along with proinflammatory cytokines (e.g., IL-1 $\beta$, IL-2, IL-6, IL-8, IL-12, and IL-18).

The costimulation paradigm dictates that strong $\mathrm{T}$ cell activation requires three distinct signals: the antigenic stimulus provided by MHC presenting a cognate peptide, costimulatory molecules, and stimulatory cytokines. Antigen presentation in the absence of strong costimulation can induce a state of antigen-specific T-cell unresponsiveness or anergy. Repetitive stimulation with allogeneic immature human DCs has been shown to induce IL-10-producing, nonproliferating $\mathrm{CD} 4^{+} \mathrm{T}$ cells with regulatory activity [90]. Systemic injection of immature, but not of mature, donor bone 


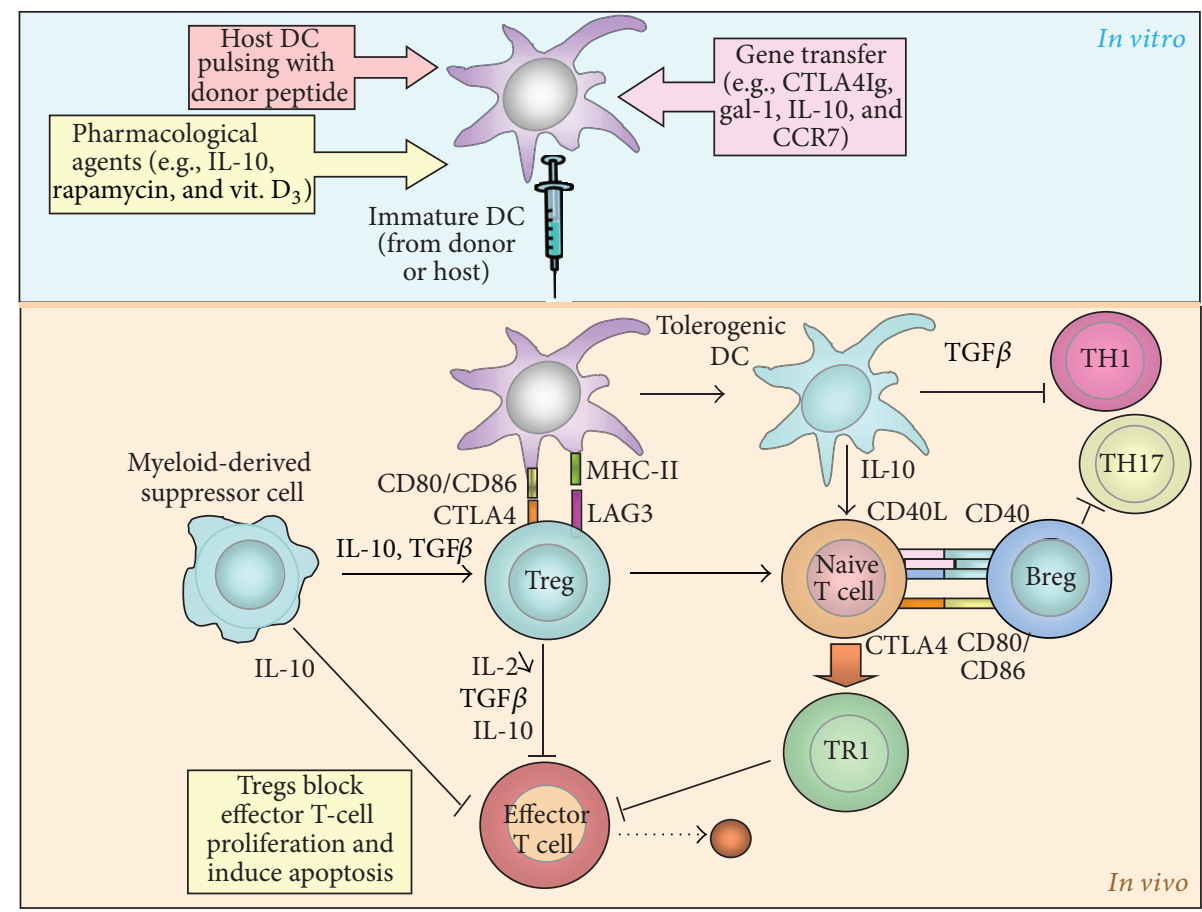

FIgURE 1: Regulatory T cells (Tregs) are present in the host at the time of transplantation and are recruited to the allograft. They respond to donor alloantigen through cross-reactivity and inhibit T-cell proliferation in draining lymphoid tissue. Tolerogenic DCs favor the generation of Tregs from naive $\mathrm{T}$ cells, which then block effector T-cell proliferation while also triggering apoptosis of these cells. They inhibit TH1 cells. These processes facilitate allograft acceptance through several mechanisms including the production and release of immunosuppressive cytokines, such as IL-10 and TGF $\beta$ (modified from Wood et al. [2]).

marrow-derived CD8 $\alpha^{-}$DCs to the recipient before engraftment prolonged cardiac allograft survival in the absence of immunosuppression in mice [91, 92]. Both immature and comparatively mature CD $8 \alpha^{+}$"lymphoid-related" DCs injected 7 days before transplantation likewise prolonged cardiac allograft survival in fully MHC-mismatched mice [93]. Moreover, systemically injected donor DCs prevented rejection of MHC-mismatched skin grafts [94] and lethal acute graft-versus-host disease [95] in mice. Immature DCs derived from recipient bone marrow progenitors similarly improved cardiac allograft survival in mice [96].

Immature DCs with inhibitory properties can be generated from monocyte precursors in vitro [97]. Alternatively, immature DC precursors can be mobilized in the live donor by Flt3L or granulocyte-colony stimulating factor (GCSF), collected by leukapheresis, purified, and injected to the recipient before transplantation. However, this is not a feasible method with deceased donors, such as in heart transplantation. In human, bone marrow cell mobilization by G-CSF preferentially increased circulating plasmacytoid DC precursors [98].

\section{DCs and Tregs}

DCs continuously present harmless self- and nonselfantigens in a way that favors tolerance. Following antigen presentation in the absence of costimulatory signals in mice, immature DCs induce conventional naive $\mathrm{T}$ cells to convert into Tregs and boost the regulatory activity of existing Tregs at once [99-106]. Immature DCs in secondary lymphoid tissue accumulate antigen and bolster the generation of Tregs that promote antigen-specific tolerance. Mice lacking functional immature DCs develop fatal autoimmune disease, possibly owing to low numbers of Tregs $[19,61,107,108]$. Mammals, including human, lacking functional Tregs likewise develop fatal autoimmune disease [109].

Regulatory DCs interact with Tregs in bidirectional ways. Tregs express inhibitory receptors, such as cytotoxic Tlymphocyte antigen 4 (CTLA4), lymphocyte-activation gene 3 (LAG-3), and glucocorticoid-induced tumor necrosis factor receptor (GITR), along with anti-inflammatory cytokines such as TGF- $\beta$, IL-10, and IL-35 $[110,111]$. TGF- $\beta$ is a central mediator in the generation of Tregs $[112,113]$. These cells can be subdivided into $\mathrm{CD} 4^{+}$natural Tregs that are formed during thymic development in the fetus [114-116] and adaptive Tregs. The transcription factor Foxp3 is upregulated in developing $\mathrm{T}$ cells upon recognition of self-antigen in the thymus and controls the function of Tregs [114, 117]. Natural Tregs can convert into adaptive $\mathrm{CD}^{+}$or $\mathrm{CD} 8^{+}$Tregs in secondary lymphoid organs. In two human volunteers, a single subcutaneous injection with autologous immature monocyte-derived DCs pulsed with influenza matrix peptide induced IL-10-producing, peptide-specific $\mathrm{CD}^{+}$Tregs and suppressed peptide-specific killing activities of $\mathrm{CD} 8^{+} \mathrm{T}$ cells [118]. These results indicate that immature DCs can induce Tregs and inhibit antigen-specific effector T cells in human. 


\section{Tolerogenic DCs}

Immature DCs are comprised of distinct populations that differ in their capacity to present antigen, produce cytokines, and promote tolerance. Phenotypically mature DCs are not always immunogenic. For instance, immature DCs that upregulate $\mathrm{MHC}$ and costimulatory molecules after in vitro treatment with TNF- $\alpha$ or IFN- $\gamma$, a typical attribute of mature DCs, but are still able to promote the generation of Tregs from naive $\mathrm{T}$ cells, have been described [119, 120]. Also, some immature DCs in peripheral tissue express high levels of CCR7, another typical feature of mature DCs, while maintaining the capacity of inducing Tregs [121-124]. CCR7 deficiency prevents lymphatic migration of immature DCs and induction of inhaled and oral tolerance, indicating a major role for this chemokine receptor in tolerance induction [125].

Plasmacytoid DCs, originally identified as a subset of DCs that produce type I interferons in response to viral infection, differ from traditional DCs in several ways including decreased costimulatory molecule expression and reduced allostimulatory capacity. Human plasmacytoid DCs preferentially express immunoglobulin-like transcript 7 (ILT7) that couples with a signaling adapter to activate a prominent immunoreceptor tyrosine-based activation motif- (ITAM) mediated signaling pathway [27]. Nonlymphoid, tissueresident plasmacytoid DCs are key cellular players in the regulation of mucosal immunity at steady state and in the induction of central and peripheral tolerance. They have been associated with generation of alloantigen-specific $\mathrm{CD} 4^{+}$ Tregs or $\mathrm{CD}^{+}$Tregs that promote graft tolerance $[26$, $54,57,126-133]$ and long-term cardiac allograft survival $[131,132]$.

Natural tolerogenic DCs originate from hematopoietic precursors and maintain tolerance constitutively under homeostatic conditions [134]. In the thymus, where central tolerance is set up, natural tolerogenic DCs induce the generation of Foxp $3^{+}$natural Tregs by a mechanism that is mediated by IL-7-related thymic stromal lymphopoietin (TSLP) produced by Hassall's corpuscles in the thymic medulla [135]. Induced tolerogenic DCs differ from natural DCs in that their tolerogenic activity is controlled by molecular signals from the environment, such as TGF- $\beta$ and IL-10 in the intestinal mucosa, which oppose maturation stimuli. In vitro treatment of immature DCs with these anti-inflammatory cytokines promotes the development of tolerogenic DCs that assist in the conversion of naive $\mathrm{T}$ cells into Tregs more effectively than the immature DCs themselves. Several strategies have been developed to generate tolerogenic DCs for therapeutic use in organ transplantation [44, 136-142]. The two major general approaches consist of pharmacological conditioning and genetic engineering of immature DCs.

5.1. Pharmacologically Conditioned DCs. The development of immunosuppressive drugs has traditionally been focused on inhibition of lymphocyte proliferation, which was initially perceived as a key process in immune responses to all kinds of antigens. By screening many agents for inhibition of lymphocyte proliferation, Schwartz and Dameshek discovered the immunosuppressant 6-mercaptopurine in 1959 [143]. Over the past two decades, it has been increasingly recognized that many drugs that primarily act by inhibiting T-cell proliferation concurrently modulate DC function.

Glucocorticoids inhibit DC differentiation and maturation both in vitro and in vivo [144-150]. Dexamethasone preferentially blocked the differentiation of plasmacytoid DCs and enhanced their apoptotic death [150]. DCs conditioned by vitamin $\mathrm{D}_{3}$ in vitro exhibited several attributes of tolerogenic DC, such as resistance to maturation, IL-10 release upon stimulation, and low T-cell allostimulatory capacity [151, 152]. Human monocyte-derived, vitamin $\mathrm{D}_{3}$-treated DCs displayed a semimature phenotype, anti-inflammatory properties, and low T-cell allostimulatory capacity [153]. T cells from patients with relapsing remitting multiple sclerosis cultured with autologous vitamin $\mathrm{D}_{3}$-treated DCs loaded with myelin peptides induced hyporesponsiveness of myelin-reactive $\mathrm{T}$ cells [153]. Synergistic effects of vitamin $\mathrm{D}_{3}$ and dexamethasone have been reported [149]. Vitamin $\mathrm{D}_{3}$ combined with dexamethasone was used to derive tolerogenic DCs from healthy subjects and from patients with rheumatoid arthritis [154]. In vitro LPS-stimulated tolerogenic DCs, referred to as "alternatively activated" DCs, exhibited enhanced ability to migrate to lymphoid tissue and to present antigen. They induced memory T-cell hyporesponsiveness, proliferation of naive T cells, low IFN- $\gamma$ expression, and high IL-10 expression $[155,156]$.

DCs conditioned by IL-10 or other immunosuppressive cytokines in vitro promoted antigen-specific anergy and regulatory activity in memory $\mathrm{CD}^{+} \mathrm{T}$ cells $[21,157]$. Two different populations of DCs were derived from monocytes cultured in the presence of GM-CSF and IL-4, depending on the time point of their exposure to IL-10. When IL-10 was added at the end of culture, DCs showed an immature phenotype, were resistant to maturation $[158,159]$, and induced antigen-specific $\mathrm{CD}^{+}$and $\mathrm{CD}^{+}$T-cell anergy [159-161]. DCs derived from macaque monocytes treated with vitamin $\mathrm{D}_{3}$ and IL-10 were resistant to maturation and displayed low T-cell allostimulatory activity in vitro [162]. Systemic injection of these DCs to MHC-mismatched recipient macaques treated with antihistamine drug and CTLA4Ig (soluble CTLA4-immunoglobulin fusion protein) elicited a transient increase in donor antigen-specific Tcell proliferation, with no changes in antidonor antibodies [162]. Conversely, when IL-10 was added at the initiation of monocyte culture, the differentiating DCs expressed CD83, CD80, and CD86, similar to mature cells, but also Ig-like transcript- (ILT-) 2, ILT3, ILT4, and human leukocyte antigen G, similar to tolerogenic DCs [163]. Importantly, IL-10treated DCs supported the differentiation of type-1 Tregs (Tr1) $[163,164]$. On the other hand, IL-10 downregulated CCR7, thereby impairing lymphoid homing of DCs in vivo $[165,166]$.

Cyclosporine A and tacrolimus (FK-506), two calcineurin inhibitors, inhibited IFN- $\gamma$ production and MHC-restricted antigen presentation by myeloid DCs [167], as well as activatory interactions of DCs with T cells [168]. In one study [169], cyclosporine A downregulated chemokine receptors and cyclooxygenase-2 (COX-2). This effect was associated 
with impaired DC migration. However, another study [166] showed that cyclosporine A and tacrolimus, unlike dexamethasone and IL-10, did not downregulate CCR7 nor did they inhibit CCL19 chemokine-mediated migration of human monocyte-derived DCs in vitro or lymphoid homing of mouse DCs in vivo.

Another important molecule used to generate tolerogenic DCs is mycophenolate mofetil. This agent inhibits T- and B-cell proliferation by interfering with de novo synthesis of purines required for the production of nucleic acids. Mycophenolate mofetil inhibits the maturation of DCs in vitro and their immunostimulatory capacity in vivo [170].

Aspirin [171-174] and deoxyspergualin [175], two inhibitors of the NF- $\kappa \mathrm{B}$ signaling pathway, likewise inhibit DC maturation. Immature host DCs conditioned ex vivo with oligodeoxynucleotides (ODN) against NF- $\kappa \mathrm{B}$ achieved longterm cardiac allograft survival in rats [176]. Blocking NF- $\kappa \mathrm{B}$ signaling during human DC differentiation induced anergy and Treg activity for one, but not two, HLA-DR mismatches [177]. Interestingly, a clinical study showed a significant correlation between low-dose aspirin therapy and improved allograft function and survival in kidney transplant recipients [178]. Systemic administration of immature autologous myeloid DCs combined with a deoxyspergualin derivative induced donor-specific tolerance in a heart transplant model in rats [20]. This effect was associated with an increase in $\mathrm{NK}^{-} \mathrm{TCR} \alpha \beta^{+} \mathrm{CD} 3^{+} \mathrm{CD} 4^{-} \mathrm{CD} 8^{-}$double negative Tregs, a population that has been linked to donor-specific improvement of graft survival [179], but not in conventional $\mathrm{CD}^{+} \mathrm{CD} 25^{+} \mathrm{Foxp}^{+}$or $\mathrm{CD} 8 \mathrm{CD} 45 \mathrm{RC}^{\text {low }}$ Tregs in host spleens. The double negative Treg population expressed IFN- $\gamma$. This cytokine is produced by alloantigen-reactive $\mathrm{CD}^{+}{ }^{+}$Foxp $^{+}$Tregs and enhances their regulatory activity in vivo through an autocrine mechanism [180]. IFN- $\gamma$ also induces the development of Foxp $3^{+}$Tregs from $\mathrm{CD}^{+}$ $\mathrm{CD} 25^{-}$cells. These findings indicate that IFN- $\gamma$ released by double negative Tregs potentiates their ability to suppress alloreactive $\mathrm{CD}^{+}$and $\mathrm{CD} 8^{+} \mathrm{T}$ cells [181].

Rapamycin, an immunosuppressive macrolide, inhibits the integrative kinase mammalian target of rapamycin (mTOR). Inhibition of mTOR exerts immunoregulatory activity [182] including attenuated innate immune responses [183]. Mouse monocyte-derived DCs conditioned by rapamycin in vitro were resistant to maturation induced by inflammatory stimuli while conserving their ability to migrate to lymphoid tissue and to enrich the naturally occurring $\mathrm{CD}^{+}{ }^{+}$Tregs. Intravenous injection of host rapamycin-treated DCs pulsed with donor antigen before heart transplantation, combined with a short course of immunosuppression, prolonged allograft survival indefinitely in rodents [28-30, 184, 185]. Rapamycin-treated DCs expressed CD83, CD86, low levels of IL-10, and high levels of IL-12p40/p70 [186]. Although these features were typical of a mature phenotype, these DCs inhibited T-cell alloproliferation, similar to those treated with vitamin D3 and dexamethasone [187]. Upon LPS stimulation, they expressed high levels of IL-12 [28], a cytokine that participates in the generation of Foxp $3^{+}$Tregs. However, human rapamycin-treated DCs, unlike murine, were only partially maturation resistant in vivo [30].

DC-mediated NK T-cell activation is a critical event in the early immune response to renal ischemia/reperfusion injury. DCs treated with adenosine $2 \mathrm{~A}$ receptor $\left(\mathrm{A}_{2} \mathrm{AR}\right)$ agonists protected the kidney from ischemia/reperfusion injury through suppression of IFN- $\gamma$ production by NK Tcells and decreased costimulatory molecule expression [31]. In a recent study [188], protein kinase $C$ inhibitors induced the development of stable human tolerogenic DCs.

5.2. DCs Generated in the Presence of Low-Dose GM-CSF without IL-4. A combination of high-dose GM-CSF and IL-4 has been used as a standard protocol for generation of DCs from bone marrow precursors in vitro. Although DCs generated using this protocol induced primary allogeneic T-cell anergy in vitro, they were not resistant to maturation. The potential of tolerogenic DCs to mature within an inflammatory environment, turning into immunogenic cells in vivo, is of major concern to therapeutic applications [47]. An alternative protocol consists of culturing bone marrow precursors with low-dose GM-CSF in the absence of IL-4. Mouse DCs generated using this protocol efficiently captured and presented antigen, were maturation-resistant and poor stimulators of T-cell proliferation, and prolonged cardiac allograft survival in vivo [92]. DCs derived from monkey bone marrow in the presence of GM-CSF without IL-4 gave rise to two populations showing a similar phenotype but different functional properties. The adherent population displayed immunoregulatory properties that were correlated with upregulation of heme oxygenase-1 (HO-1), an antiinflammatory enzyme, both in vitro and in a rat allotransplant model in vivo. Conversely, the nonadherent population was immunogenic [189]. Immature DCs derived from human bone marrow by low doses of GM-CSF in the absence of IL- 4 were resistant to common maturation stimuli and exhibited tolerogenic properties in vitro $[47,190]$, including induction of T-cell anergy in naive allogeneic $\mathrm{T}$ cells when stimulated twice with immature DCs [47]. Therefore, the establishment of the anergic state appeared to require two subsequent stimulations by immature DCs.

\subsection{Tolerogenic DC Therapy Combined with Immunosup-} pressive Drug Administration. In vivo injection of immature DCs can be combined with the systemic administration of immunosuppressive drugs. For instance, immature donor DC therapy combined with either anti-CD154 (CD40 ligand) antibody [191] or anti-CD54 (intercellular adhesion molecule) antibody together with CTLA4Ig [192] prolonged cardiac allograft survival in mice for more than 100 days. Likewise, adoptive transfer of immature donor DCs combined with anti-CD154 antibody inhibited intimal hyperplasia and arterial lesions in mouse aortic allografts [193]. Alloantigen-pulsed, rapamycin-treated DCs combined with a low dose of rapamycin administered at the time of transplantation induced indefinite cardiac allograft survival in mice [184]. Moreover, mature donor DCs combined with a systemic treatment with tacrolimus prolonged cardiac 
allograft survival in rats, whereas DCs alone were ineffective in this model [194]. Other studies did not support synergistic effects of tolerogenic DC therapy and systemic treatment with rapamycin or cyclosporine $\mathrm{A}$ in transplant models [167]. On the other hand, immunosuppressive drugs can modify DC function and hinder the efficacy of tolerogenic DC therapy. As an example, tacrolimus inhibits the ability of DCs to process and/or present antigen [167, 195]. For these reasons, interactions of systemic drug treatments with injected tolerogenic DCs need to be investigated in animal models before the initiation of clinical trials, as discussed below.

5.4. Genetically Modified DCs. One critical aspect of tolerogenic DC therapy is the stability of tolerogenic DCs, which should not turn into immunogenic DCs in vivo when exposed to proinflammatory cytokines. This consideration is important in transplantation, a condition associated with chronic inflammation. Semimature tolerogenic DCs have been shown to convert into immunogenic DCs in an inflammatory environment in vivo $[196,197]$, which can accelerate graft rejection. Because the conditioning effect by pharmacological agents on DCs in vitro may not last in vivo, genetic engineering of DCs to express an immunosuppressive factor may represent an attractive approach. Genetically modified DCs can express the therapeutic gene for extended periods of time in vivo. Because DCs are manipulated genetically in vitro, the recipient is not directly exposed to the gene transfer vector. Recombinant adenovirus vectors have been used in many studies due to their high efficiency, despite their proinflammatory effects that entail DC maturation [198]. Recombinant retrovirus vectors and nonviral gene transfer systems may induce lower levels of DC maturation [199]. With respect to the transgene which is to be constitutively expressed by DCs, candidates include genes that encode an immunosuppressive cytokine, a costimulatory inhibitor, a death ligand that causes killing of effector $\mathrm{T}$ cells, a chemokine receptor, or an adhesion molecule that mediates lymphoid homing, among others.

Early studies focused on DCs constitutively expressing immunosuppressive cytokines, particularly IL-10, IL-4, and TGF- $\beta$ [200-208]. These approaches had limited effects on allograft survival. We have shown that bone marrowderived mouse DCs constitutively expressing indoleamine 2,3-dioxygenase (IDO), an inhibitor of T-cell activation, attenuated T-cell alloproliferative responses in the mixed leukocyte reaction in vitro [209]. DCs expressing soluble CTLA4Ig significantly prolonged both cardiac and islet allograft survival in rodents [210-214]. However, this approach was not significantly more effective than CTLA4Ig peptide treatment or direct CTLA4Ig gene delivery into the graft.

By binding the cell death receptor Fas (CD95), Fas ligand participates in the maintenance of peripheral T-cell tolerance and maintenance of immune privilege in certain organs. DCs expressing transgenic Fas ligand inhibited antigen-specific Tcell responsiveness, prolonging the survival of fully MHCmismatched cardiac allografts in some studies [215, 216], but not in others $[217,218]$. Mouse tolerogenic DCs generated with antisense ODN against the costimulatory molecules CD40, CD80, and CD86 remained costimulatory deficient in vivo, even after 3 weeks of injection [219]. Low CD40 expression translates into low levels of cytokine (IL-12, TNF$\alpha$ ) production upon CD40 ligation [219]. DCs generated with antisense ODN against CD80/86 prolonged allograft survival in a transplant model [220]. Similar findings were reported with immature DCs constitutively expressing soluble TNF- $\alpha$ type-1 receptor (sTNFR-1) [221]. DCs engineered genetically to express CCR7 showed enhanced lymphoid homing. Injection of DCs constitutively expressing both IL-10 and CCR7, but not those expressing either gene alone, prolonged cardiac allograft survival in mice [222]. This finding exemplifies synergistic effects resulting from simultaneous targeting of multiple parameters of DC function, such as maturation and lymphoid homing.

Galectin- (gal-) 1 is an endogenous inhibitor of T-cell activation, DC function, and immune cell trafficking [223225]. DCs deliver tolerogenic signals to T cells through a gal1-driven immunoregulatory circuit that involves IL-27 and IL-10 [226]. Lung cancer-derived gal-1 mediates DC anergy through inhibitor of DNA binding 3/IL-10 signaling pathway [227]. Gal-1 and -3 genes silencing in immature and mature DCs enhance T-cell activation and IFN- $\gamma$ production [228]. DCs constitutively expressing gal-1 delayed onset of autoimmune diabetes in mice [223]. Moreover, gal-1 prolonged liver allograft survival from Flt3L-pretreated donors in mice [229]. Mice deficient in gal-1 showed accelerated $\mathrm{CD} 8^{+} \mathrm{T}-$ cell-mediated rejection of skin allografts [230]. These findings establish gal-1 as an attractive candidate for gene therapy for transplantation.

5.5. DCs Conditioned by Donor Apoptotic Cells and Exosomes. An emerging strategy consists of in situ delivery of donor antigen to quiescent host DCs using donor apoptotic cells or exosomes [231, 232]. The latter are $40-100 \mathrm{~nm}$ size membrane vesicles rich in microRNA, which play important roles in intercellular communication [233], including the transfer of functional microRNA molecules between DCs [35]. Interaction or phagocytosis of cells in early apoptosis exerts a potent anti-inflammatory and immunosuppressive stimulus on DCs and macrophages. In situ-targeting of DCs with donor apoptotic cells restrained indirect allorecognition and attenuated graft vasculopathy in a transplant model [234]. Systemically delivered exosomes rich in donor MHC molecules were taken up by host DCs and prolonged allograft survival [231]. Exosomes from immature DCs combined with rapamycin induced tolerance to cardiac allografts in mice [36].

5.6. Tolerogenic DC Therapy May Act through Conventional DCs of the Host. Recent evidence suggests that in vivo injected immunosuppressive DCs may attenuate alloresponses and improve cardiac allograft survival, not by themselves, but through quiescent conventional DCs of the recipient [33, 34]. Indeed, transient depletion of conventional DCs of the recipient by the time of DC therapy abolished its beneficial effect on graft survival. This phenomenon was 
also observed when immunosuppressive DCs were combined with low-dose pharmacological immunosuppression. Following DC therapy, presentation of donor-derived peptides by conventional DCs led to preferential deletion of indirectpathway $\mathrm{CD}^{+}$effector $\mathrm{T}$ cells, increasing the percentage of Foxp $3^{+} \mathrm{CD}^{+} \mathrm{T}$ cells [33]. These results are in line with earlier studies showing that i.v. injection of donor immunosuppressive DCs before heart transplantation inhibited antidonor responses through the direct pathway, which involves recognition of intact donor $\mathrm{MHC}$ molecules by recipient $\mathrm{T}$ cells $[92,210]$. The high precursor frequency of directpathway $\mathrm{T}$ cells and their predominance in most in vitro assays of alloreactivity led to the assumption that the direct pathway was the dominant mechanism of allorecognition during acute cardiac allograft rejection and that systemic injection of donor immunosuppressive DCs inhibited direct responses by interacting with direct-pathway $\mathrm{T}$ cells [34]. The aforementioned findings regarding transient depletion of recipient DCs at the time of donor DC therapy [33] demonstrate that depletion of conventional DCs prevents not only downregulation of the indirect T-cell pathway, as anticipated, but also the direct-pathway response elicited by cardiac allografts. This observation suggests that, in vivo, donor-derived immunosuppressive DCs by themselves are unable to downregulate direct T-cell responses in the absence of conventional DCs of the recipient [34].

Because generation of donor immunosuppressive DCs is not applicable to deceased donors, use of host DCs pulsed with donor antigen has been viewed as a more feasible method in clinical heart transplantation. Within this context, pulsing host DCs with donor antigen has been used to inhibit the indirect pathway of allorecognition $[235,236]$. However, the aforementioned study [33] indicated that systemically injected host immunosuppressive DCs pulsed with MHC class I- or MHC class II-restricted peptides mediated their beneficial effect through conventional DCs of the recipient. These findings suggest that the intrinsic immune regulatory activity of delivered DCs in vivo may be less important than what was previously thought. They also raise the question as to whether the function of conventional DCs of the recipients, which are required for the efficacy of DC therapies, is preserved in transplant candidates with an end-stage disease.

5.7. Clinical Applications of Tolerogenic DCs. While several clinical trials of immunogenic DC therapy for cancer have been performed [237, 238], clinical DC-based "negative vaccination" is still very much in its infancy. In 2001, a pioneering study showed that autologous immature DCs injected subcutaneously into healthy volunteers were well tolerated, did not cause autoimmunity, and induced antigen-specific $\mathrm{CD}^{+}$ Tregs along with antigen-specific T-cell hyporesponsiveness $[118,239]$. Recently, proof of safety for tolerogenic DC therapy was provided by a clinical phase- 1 trial in 10 patients with type-1 diabetes who received an intradermal injection of autologous DCs generated in the presence of GM-CSF and IL-4, with or without antisense ODN against CD40, CD80, and C86 [37]. No adverse effects were observed. Meanwhile, two clinical trials of tolerogenic DC therapy in patients with rheumatoid arthritis have been started [38, 240]. Other trials are in progress or are imminent. In transplantation, the OneStudy phase-1 clinical trial has been designed to evaluate tolerogenic DC therapy in renal transplant recipients [39, 241]. Autologous monocyte-derived tolerogenic DCs will be generated from patients with chronic renal failure. Each disease condition for which DC therapy is envisaged can potentially modify the function and in vivo survival of tolerogenic DCs derived from the recipient. It therefore is important to test DCs from patients in animal models before starting a clinical trial. Ahead of the clinical trial in kidney transplantation, tolerogenic DCs from patients with chronic renal failure have been validated in a skin transplant model [241]. Moreover, tolerogenic DCs from patients with rheumatoid arthritis were compared with those from healthy controls before the initiation of a clinical trial for this disease; tolerogenic DCs from the two groups showed a similar phenotype and in vitro function [154]. Ahead of a clinical trial in patients with relapsing-remitting multiple sclerosis, tolerogenic DCs generated with vitamin $\mathrm{D}_{3}$ from these patients were compared with those derived from healthy controls and found to have a comparable phenotype and function [153].

In renal transplant recipients enrolled in the OneStudy trial and treated with tolerogenic DC therapy, drug-based immunosuppression consisting of low doses of mycophenolate mofetil, tacrolimus, and prednisolone is not discontinued [241]. This raises the question as to whether these drugs could modify the function of injected tolerogenic DCs in vivo. As already mentioned, immunosuppressive drugs can either enhance or hamper the effect of DC therapy. In preliminary experiments performed ahead of the OneStudy trial, tolerogenic DC therapy did not impair, but actually slightly enhanced, the effect of mycophenolate mofetil on graft survival in a transplant model [241]. While tacrolimus inhibits the ability of DCs to process and/or present antigen $[167,195]$, tacrolimus immunosuppression has been shown to prolong cardiac allograft survival after in vivo injection of mature donor DCs in a transplant model [194]. Before the initiation of a clinical trial, it is therefore important to assess graft survival with each immunosuppressive drug to be used in the trial, with and without DC therapy, in a transplant model.

Another aspect that affects immunogenicity and survival of injected DCs in vivo is the route of administration. In one study [242], dexamethasone/LPS-treated DCs prolonged mouse cardiac allograft survival when delivered intravenously, whereas they were ineffective when delivered subcutaneously. Recent evidence in monkeys suggests that autologous tolerogenic DCs may prime an immune response when delivered intradermally, but not when delivered intravenously [39]. In another study in monkeys, intravenous injection of tolerogenic DCs was well tolerated [162].

An unresolved issue in DC therapy for transplantation is the choice between donor and recipient DCs. Most studies have utilized donor DCs or recipient DCs loaded with donor peptides. The OneStudy trial in kidney transplantation has been designed to evaluate autologous DCs not pulsed with donor antigens [39]. The investigators pointed out that a risk 
of donor sensitization due to the presence of a slight contaminant cell product or the destruction of the injected cells by nonself-recognition [243] could not be excluded using tolerogenic DCs from the donor [39], whereas such a risk should be minimized using autologous DCs. In addition, donor DCs or recipient DCs pulsed with donor peptides require LPS or cytokine stimulation for efficient lymphoid homing and antigen presentation in transplant models ("alternatively activated" DCs) $[155,156]$; however, such a stimulation can foster DC maturation. On the contrary, autologous immature DCs do not need LPS stimulation in rodent transplant models [96]. Also, recent evidence suggests donor DCs may die quickly after in vivo injection, and the effect of DC therapy may be mediated by endogenous DCs $[33,34]$, as discussed above. To the opposite, autologous immature DCs have been detected in the spleen of recipient rats at least two weeks after in vivo injection [96]. Thus, autologous DCs may offer several advantages over donor DCs as a source for tolerogenic DCs [39]; however, this question has not been answered definitively.

\section{Concluding Remarks}

Studies in rodent and monkey transplant models have provided proof of principle for tolerogenic DC therapy for solidorgan transplantation. Clinical trials testing this strategy have been carried out in patients with type-1 diabetes or rheumatoid arthritis, and a trial in renal transplant recipients has been designed. Nevertheless, several important questions remain. Are autologous DCs superior to donor DCs? Should autologous DCs be pulsed with donor antigen? Are genetically engineered DCs superior to pharmacologically conditioned DCs? Does maintenance drug-based immunosuppression influence the outcome of DC therapy? Which immunosuppressive drugs are most suitable in this regard? What is the best time for DC administration? How can DCs be made truly maturation resistant in vivo? As conventional DCs of the recipient seem to be critical for the success of tolerogenic DC therapy, would it be possible to promote tolerance without any cell injection? Answering these questions will likely advance the field and optimize these approaches. Meanwhile, a successful completion of the first clinical trial of DC therapy in transplantation may open a new avenue in the field.

\section{Conflict of Interests}

The author declares that there is no conflict of interests regarding the publication of this paper.

\section{Acknowledgment}

The author is grateful for funding support from the Swiss National Science Foundation (Research Grant 310030118210), the Fondation Vaudoise de Cardiologie, and the Cecilia Augusta Foundation.

\section{References}

[1] K. J. Wood and R. Goto, "Mechanisms of rejection: current perspectives," Transplantation, vol. 93, no. 1, pp. 1-10, 2012.

[2] K. J. Wood, A. Bushell, and J. Hester, "Regulatory immune cells in transplantation," Nature Reviews Immunology, vol. 12, pp. 417-430, 2012.

[3] S. I. Alexander, N. Smith, D. Verran et al., "Chimerism and tolerance in a recipient of a deceased-donor liver transplant," The New England Journal of Medicine, vol. 358, no. 4, pp. 369374, 2008.

[4] L. J. West, "ABO-incompatible hearts for infant transplantation," Current Opinion in Organ Transplantation, vol. 16, no. 5, pp. 548-554, 2011.

[5] M. Takatsuki, S. Uemoto, Y. Inomata et al., "Weaning of immunosuppression in living donor liver transplant recipients," Transplantation, vol. 72, no. 3, pp. 449-454, 2001.

[6] S. Strober, M. Dhillon, M. Schubert et al., "Acquired immune tolerance to cadaveric renal allografts. A study of three patients treated with total lymphoid irradiation," The New England Journal of Medicine, vol. 321, no. 1, pp. 28-33, 1989.

[7] T. Kawai, D. H. Sachs, M. Sykes, A. B. Cosimi, and Immune Tolerance Network, "HLA-mismatched renal transplantation without maintenance immunosuppression," The New England Journal of Medicine, vol. 368, no. 19, pp. 1850-1852, 2013.

[8] J. D. Scandling, S. Busque, S. Dejbakhsh-Jones et al., "Tolerance and withdrawal of immunosuppressive drugs in patients given kidney and hematopoietic cell transplants," American Journal of Transplantation, vol. 12, no. 5, pp. 1133-1145, 2012.

[9] J. Leventhal, M. Abecassis, J. Miller et al., "Tolerance induction in HLA disparate living donor kidney transplantation by donor stem cell infusion: durable chimerism predicts outcome," Transplantation, vol. 95, no. 1, pp. 169-176, 2013.

[10] A. D. Salama, G. Remuzzi, W. E. Harmon, and M. H. Sayegh, "Challenges to achieving clinical transplantation tolerance," Journal of Clinical Investigation, vol. 108, no. 7, pp. 943-948, 2001.

[11] R. E. Billingham, L. Brent, and P. B. Medawar, "Actively acquired tolerance' of foreign cells," Nature, vol. 172, no. 4379, pp. 603-606, 1953.

[12] B. M. Hall, M. E. Jelbart, and S. E. Dorsch, "Suppressor T cells in rats with prolonged cardiac allograft survival after treatment with cyclosporine," Transplantation, vol. 37, no. 6, pp. 595-600, 1984.

[13] K. J. Wood and S. Sakaguchi, "Regulatory T cells in transplantation tolerance," Nature Reviews Immunology, vol. 3, no. 3, pp. 199-210, 2003.

[14] Y. Li, T. Koshiba, A. Yoshizawa et al., "Analyses of peripheral blood mononuclear cells in operational tolerance after pediatric living donor liver transplantation," American Journal of Transplantation, vol. 4, no. 12, pp. 2118-2125, 2004.

[15] M. Martínez-Llordella, I. Puig-Pey, G. Orlando et al., "Multiparameter immune profiling of operational tolerance in liver transplantation," American Journal of Transplantation, vol. 7, no. 2, pp. 309-319, 2007.

[16] S. Brouard, E. Mansfield, C. Braud et al., "Identification of a peripheral blood transcriptional biomarker panel associated with operational renal allograft tolerance," Proceedings of the National Academy of Sciences of the United States of America, vol. 104, no. 39, pp. 15448-15453, 2007.

[17] K. A. Newell, A. Asare, A. D. Kirk et al., "Identification of a B cell signature associated with renal transplant tolerance in humans," 
Journal of Clinical Investigation, vol. 120, no. 6, pp. 1836-1847, 2010.

[18] P. Sagoo, E. Perucha, B. Sawitzki et al., "Development of a cross-platform biomarker signature to detect renal transplant tolerance in humans," Journal of Clinical Investigation, vol. 120, no. 6, pp. 1848-1861, 2010.

[19] C. Ohnmacht, A. Pullner, S. B. S. King et al., "Constitutive ablation of dendritic cells breaks self-tolerance of CD4 T cells and results in spontaneous fatal autoimmunity," Journal of Experimental Medicine, vol. 206, no. 3, pp. 549-559, 2009.

[20] M. Hill, P. Thebault, M. Segovia et al., "Cell therapy with autologous tolerogenic dendritic cells induces allograft tolerance through interferon-gamma and Epstein-Barr virus-induced gene 3," American Journal of Transplantation, vol. 11, no. 10, pp. 2036-2045, 2011.

[21] H. Torres-Aguilar, S. R. Aguilar-Ruiz, G. González-Pérez et al., "Tolerogenic dendritic cells generated with different immunosuppressive cytokines induce antigen-specific anergy and regulatory properties in memory $\mathrm{CD} 4^{+} \mathrm{T}$ cells," Journal of Immunology, vol. 184, no. 4, pp. 1765-1775, 2010.

[22] K. Liu and M. C. Nussenzweig, "Origin and development of dendritic cells," Immunological Reviews, vol. 234, no. 1, pp. 4554, 2010.

[23] R. M. Steinman and J. Idoyaga, "Features of the dendritic cell lineage," Immunological Reviews, vol. 234, no. 1, pp. 5-17, 2010.

[24] S. Laffont and F. Powrie, "Immunology: dendritic-cell genealogy," Nature, vol. 462, no. 7274, pp. 732-733, 2009.

[25] K. Crozat, R. Guiton, M. Guilliams et al., "Comparative genomics as a tool to reveal functional equivalences between human and mouse dendritic cell subsets," Immunological Reviews, vol. 234, no. 1, pp. 177-198, 2010.

[26] N. M. Rogers, J. S. Isenberg, and A. W. Thomson, "Plasmacytoid dendritic cells: no longer an enigma and now key to transplant tolerance?" American Journal of Transplantation, vol. 13, no. 5, pp. 1125-1133, 2013.

[27] W. Cao and L. Bover, "Signaling and ligand interaction of ILT7: receptor-mediated regulatory mechanisms for plasmacytoid dendritic cells," Immunological Reviews, vol. 234, no. 1, pp. 163$176,2010$.

[28] A. W. Thomson, R. Fischer, H. R. Turnquist, and T. Taner, "Use of rapamycin in the induction of tolerogenic dendritic cells," Handbook of Experimental Pharmacology, vol. 188, pp. 215-232, 2009.

[29] R. T. Fischer, H. R. Turnquist, Z. Wang, D. Beer-Stolz, and A. W. Thomson, "Rapamycin-conditioned, alloantigen-pulsed myeloid dendritic cells present donor MHC class I/peptide via the semi-direct pathway and inhibit survival of antigen-specific $\mathrm{CD}^{+} \mathrm{T}$ cells in vitro and in vivo," Transplant Immunology, vol. 25, no. 1, pp. 20-26, 2011.

[30] C. Macedo, H. Turquist, D. Metes, and A. W. Thomson, "Immunoregulatory properties of rapamycin-conditioned monocyte-derived dendritic cells and their role in transplantation," Transplantation Research, vol. 1, no. 1, article 16, 2012.

[31] L. Li, L. Huang, H. Ye et al., "Dendritic cells tolerized with adenosine A2AR agonist attenuate acute kidney injury," Journal of Clinical Investigation, vol. 122, no. 11, pp. 3931-3942, 2012.

[32] T. Nikolic and B. O. Roep, "Regulatory multitasking of tolerogenic dendritic cells-lessons taken from vitamin d3-treated tolerogenic dendritic cells," Frontiers in Immunology, vol. 4, article 113, 2013.
[33] S. J. Divito, Z. Wang, W. J. Shufesky et al., "Endogenous dendritic cells mediate the effects of intravenously injected therapeutic immunosuppressive dendritic cells in transplantation," Blood, vol. 116, no. 15, pp. 2694-2705, 2010.

[34] Z. Wang, S. J. Divito, W. J. Shufesky et al., "Dendritic cell therapies in transplantation revisited: deletion of recipient DCs deters the effect of therapeutic DCs," American Journal of Transplantation, vol. 12, no. 6, pp. 1398-1408, 2012.

[35] A. Montecalvo, A. T. Larregina, W. J. Shufesky et al., "Mechanism of transfer of functional microRNAs between mouse dendritic cells via exosomes," Blood, vol. 119, no. 3, pp. 756-766, 2012.

[36] X. Li, J. J. Li, J. Y. Yang et al., "Tolerance induction by exosomes from immature dendritic cells and rapamycin in a mouse cardiac allograft model," PLOS ONE, vol. 7, no. 8, Article ID e44045, 2012.

[37] N. Giannoukakis, B. Phillips, D. Finegold, J. Harnaha, and M. Trucco, "Phase I, (safety) study of autologous tolerogenic dendritic cells in type 1 diabetic patients," Diabetes Care, vol. 34, pp. 2026-2032, 2011.

[38] C. M. Hilkens and J. D. Isaacs, "Tolerogenic dendritic cell therapy for rheumatoid arthritis: where are we now?" Clinical and Experimental Immunology, vol. 172, no. 2, pp. 148-157, 2013.

[39] A. Moreau, E. Varey, L. Bouchet-Delbos, and M. C. Cuturi, "Cell therapy using tolerogenic dendritic cells in transplantation," Transplantation Research, vol. 1, article 13, 2012.

[40] J. Banchereau, F. Briere, C. Caux et al., "Immunobiology of dendritic cells," Annual Review of Immunology, vol. 18, pp. 767811,2000

[41] D. Hawiger, K. Inaba, Y. Dorsett et al., "Dendritic cells induce peripheral $\mathrm{T}$ cell unresponsiveness under steady state conditions in vivo," Journal of Experimental Medicine, vol. 194, no. 6, pp. 769-779, 2001.

[42] G. Süss and K. Shortman, "A subclass of dendritic cells kills CD4 T cells via Fas/Fas-ligand-induced apoptosis," Journal of Experimental Medicine, vol. 183, no. 4, pp. 1789-1796, 1996.

[43] R. A. Maldonado and U. H. von Andrian, "How tolerogenic dendritic cells induce regulatory T cells," Advances in Immunology, vol. 108, pp. 111-165, 2010.

[44] A. E. Morelli and A. W. Thomson, "Tolerogenic dendritic cells and the quest for transplant tolerance," Nature Reviews Immunology, vol. 7, no. 8, pp. 610-621, 2007.

[45] K. Pletinckx, A. Döhler, V. Pavlovic, and M. B. Lutz, "Role of dendritic cell maturity/costimulation for generation, homeostasis, and suppressive activity of regulatory T cells," Frontiers in Immunology, vol. 2, article 39, 2011.

[46] M. Ezzelarab and A. W. Thomson, "Tolerogenic dendritic cells and their role in transplantation," Seminars in Immunology, vol. 23, no. 4, pp. 252-263, 2011.

[47] T. G. Berger, H. Schulze-Koops, M. Schäfer, E. Müller, and M. B. Lutz, "Immature and maturation-resistant human dendritic cells generated from bone marrow require two stimulations to induce T cell anergy in vitro," PLoS ONE, vol. 4, no. 8, Article ID e6645, 2009.

[48] H. Ueno, E. Klechevsky, R. Morita et al., "Dendritic cell subsets in health and disease," Immunological Reviews, vol. 219, no. 1, pp. 118-142, 2007.

[49] B. Pulendran, H. Tang, and T. L. Denning, "Division of labor, plasticity, and crosstalk between dendritic cell subsets," Current Opinion in Immunology, vol. 20, no. 1, pp. 61-67, 2008. 
[50] K. R. R. Siddiqui and F. Powrie, "CD103 ${ }^{+}$GALT DCs promote Foxp3+ regulatory T cells," Mucosal Immunology, vol. 1, no. 1, pp. S34-S38, 2008.

[51] K. Shortman and W. R. Heath, "The CD8 ${ }^{+}$dendritic cell subset," Immunological Reviews, vol. 234, no. 1, pp. 18-31, 2010.

[52] C. Coquerelle and M. Moser, "DC subsets in positive and negative regulation of immunity," Immunological Reviews, vol. 234, no. 1, pp. 317-334, 2010.

[53] S. Milling, U. Yrlid, V. Cerovic, and G. MacPherson, "Subsets of migrating intestinal dendritic cells," Immunological Reviews, vol. 234, no. 1, pp. 259-267, 2010.

[54] M. Swiecki and M. Colonna, "Unraveling the functions of plasmacytoid dendritic cells during viral infections, autoimmunity, and tolerance," Immunological Reviews, vol. 234, no. 1, pp. 142$162,2010$.

[55] D. Vremec, M. Zorbas, R. Scollay et al., "The surface phenotype of dendritic cells purified from mouse thymus and spleen: investigation of the CD8 expression by a subpopulation of dendritic cells," Journal of Experimental Medicine, vol. 176, no. 1, pp. 47-58, 1992.

[56] X. Ju, G. Clark, and D. N. J. Hart, "Review of human DC subtypes," Methods in Molecular Biology, vol. 595, pp. 3-20, 2010.

[57] A. G. Jegalian, F. Facchetti, and E. S. Jaffe, "Plasmacytoid dendritic cells physiologic roles and pathologic states," Advances in Anatomic Pathology, vol. 16, no. 6, pp. 392-404, 2009.

[58] C. Varol, L. Landsman, D. K. Fogg et al., "Monocytes give rise to mucosal, but not splenic, conventional dendritic cells," Journal of Experimental Medicine, vol. 204, no. 1, pp. 171-180, 2007.

[59] M. A. Schmid, D. Kingston, S. Boddupalli, and M. G. Manz, "Instructive cytokine signals in dendritic cell lineage commitment," Immunological Reviews, vol. 234, no. 1, pp. 32-44, 2010.

[60] J. Helft, F. Ginhoux, M. Bogunovic, and M. Merad, "Origin and functional heterogeneity of non-lymphoid tissue dendritic cells in mice," Immunological Reviews, vol. 234, no. 1, pp. 55-75, 2010.

[61] L. Bar-On and S. Jung, "Defining dendritic cells by conditional and constitutive cell ablation," Immunological Reviews, vol. 234, no. 1, pp. 76-89, 2010.

[62] N. Romani, B. E. Clausen, and P. Stoitzner, "Langerhans cells and more: langerin-expressing dendritic cell subsets in the skin," Immunological Reviews, vol. 234, no. 1, pp. 120-141, 2010.

[63] R. Maarten Egeler, A. G. S. Van Halteren, P. C. W. Hogendoorn, J. D. Laman, and P. J. M. Leenen, "Langerhans cell histiocytosis: fascinating dynamics of the dendritic cell-macrophage lineage," Immunological Reviews, vol. 234, no. 1, pp. 213-232, 2010.

[64] S.-Y. Chang and M.-N. Kweon, "Langerin-expressing dendritic cells in gut-associated lymphoid tissues," Immunological Reviews, vol. 234, no. 1, pp. 233-246, 2010.

[65] H. Tezuka and T. Ohteki, "Regulation of intestinal homeostasis by dendritic cells," Immunological Reviews, vol. 234, no. 1, pp. 247-258, 2010.

[66] M.-L. Del Rio, G. Bernhardt, J.-I. Rodriguez-Barbosa, and R. Förster, "Development and functional specialization of $\mathrm{CD}_{103}{ }^{+}$ dendritic cells," Immunological Reviews, vol. 234, no. 1, pp. 268 281, 2010.

[67] A. M. Kerrigan and G. D. Brown, "Syk-coupled C-type lectin receptors that mediate cellular activation via single tyrosine based activation motifs," Immunological Reviews, vol. 234, no. 1, pp. 335-352, 2010.

[68] B. León, M. López-Bravo, and C. Ardavín, "Monocyte-derived dendritic cells formed at the infection site control the induction of protective T helper 1 responses against leishmania," Immunity, vol. 26, no. 4, pp. 519-531, 2007.

[69] N. V. Serbina, T. P. Salazar-Mather, C. A. Biron, W. A. Kuziel, and E. G. Pamer, "TNF/iNOS-producing dendritic cells mediate innate immune defense against bacterial infection," Immunity, vol. 19, no. 1, pp. 59-70, 2003.

[70] F. Sallusto, P. Schaerli, P. Loetscher et al., "Rapid and coordinated switch in chemokine receptor expression during dendritic cell maturation," European Journal of Immunology, vol. 28, pp. 2760-2769, 1998.

[71] F. Re and J. L. Strominger, "Heterogeneity of TLR-induced responses in dendritic cells: from innate to adaptive immunity," Immunobiology, vol. 209, no. 1-2, pp. 191-198, 2004.

[72] E. Meylan and J. Tschopp, “Toll-like receptors and RNA helicases: two parallel ways to trigger antiviral responses," Molecular Cell, vol. 22, no. 5, pp. 561-569, 2006.

[73] R. M. Steinman, G. Kaplan, M. D. Witmer, and Z. A. Cohn, "Identification of a novel cell type in peripheral lymphoid organs of mice. V. Purification of spleen dendritic cells, new surface markers, and maintenance in vitro," Journal of Experimental Medicine, vol. 149, no. 1, pp. 1-16, 1979.

[74] W. C. Van Voorhis, L. S. Hair, R. M. Steinman, and G. Kaplan, "Human dendritic cells. Enrichment and characterization from peripheral blood," Journal of Experimental Medicine, vol. 155, no. 4, pp. 1172-1187, 1982.

[75] Ö. Türeci, H. Bian, F. O. Nestle et al., "Cascades of transcriptional induction during dendritic cell maturation revealed by genome-wide expression analysis," FASEB Journal, vol. 17, no. 8, pp. 836-847, 2003.

[76] D. Mcllroy, S. Tanguy-Royer, N. Le Meur et al., "Profiling dendritic cell maturation with dedicated microarrays," Journal of Leukocyte Biology, vol. 78, no. 3, pp. 794-803, 2005.

[77] M.-C. Dieu, B. Vanbervliet, A. Vicari et al., "Selective recruitment of immature and mature dendritic cells by distinct chemokines expressed in different anatomic sites," Journal of Experimental Medicine, vol. 188, no. 2, pp. 373-386, 1998.

[78] A. Martín-Fontecha, S. Sebastiani, U. E. Höpken et al., "Regulation of dendritic cell migration to the draining lymph node: impact on T lymphocyte traffic and priming," Journal of Experimental Medicine, vol. 198, no. 4, pp. 615-621, 2003.

[79] R. M. Steinman and Z. A. Cohn, "Identification of a novel cell type in peripheral lymphoid organs of mice. I. Morphology, quantitation, tissue distribution," Journal of Experimental Medicine, vol. 137, pp. 1142-1162, 1973.

[80] R. L. Lindquist, G. Shakhar, D. Dudziak et al., "Visualizing dendritic cell networks in vivo," Nature Immunology, vol. 5, no. 12, pp. 1243-1250, 2004.

[81] K. Inaba, M. Inaba, M. Naito, and R. M. Steinman, "Dendritic cell progenitors phagocytose particulates, including Bacillus Calmette-Guerin organisms, and sensitize mice to mycobacterial antigens in vivo," Journal of Experimental Medicine, vol. 178, no. 2, pp. 479-488, 1993.

[82] F.-P. Huang, N. Platt, M. Wykes et al., "A discrete subpopulation of dendritic cells transports apoptotic intestinal epithelial cells to T cell areas of mesenteric lymph nodes," Journal of Experimental Medicine, vol. 191, no. 3, pp. 435-443, 2000.

[83] W. R. Heath, G. T. Belz, G. M. N. Behrens et al., "Crosspresentation, dendritic cell subsets, and the generation of immunity to cellular antigens," Immunological Reviews, vol. 199, pp. 9-26, 2004. 
[84] D. Schmid, M. Pypaert, and C. Münz, "Antigen-loading compartments for major histocompatibility complex class ii molecules continuously receive input from autophagosomes," Immunity, vol. 26, no. 1, pp. 79-92, 2007.

[85] K. Inaba, S. Turley, T. Iyoda et al., “The formation of immunogenic major histocompatibility complex class II-peptide ligands in lysosomal compartments of dendritic cells is regulated by inflammatory stimuli," Journal of Experimental Medicine, vol. 191, no. 6, pp. 927-936, 2000.

[86] S. J. Turley, K. Inaba, W. S. Garrett et al., "Transport of peptideMHC class II complexes in developing dendritic cells," Science, vol. 288, no. 5465, pp. 522-527, 2000.

[87] A. Chow, D. Toomre, W. Garrett, and I. Mellman, "Dendritic cell maturation triggers retrograde MHC class II transport from lysosomes to the plasma membrane," Nature, vol. 418, no. 6901, pp. 988-994, 2002.

[88] M. H. Sayegh and L. A. Turka, "Thr role of T-cell costimulatory activation pathways in transplant rejection," The New England Journal of Medicine, vol. 338, no. 25, pp. 1813-1821, 1998.

[89] S. J. F. Cronin and J. M. Penninger, "From T-cell activation signals to signaling control of anti-cancer immunity," Immunological Reviews, vol. 220, no. 1, pp. 151-168, 2007.

[90] H. Jonuleit, E. Schmitt, G. Schuler, J. Knop, and A. H. Enk, "Induction of interleukin 10-producing, nonproliferating $\mathrm{CD}^{+}$ $\mathrm{T}$ cells with regulatory properties by repetitive stimulation with allogeneic immature human dendritic cells," Journal of Experimental Medicine, vol. 192, no. 9, pp. 1213-1222, 2000.

[91] F. Fu, Y. Li, S. Qian et al., "Costimulatory molecule-deficient dendritic cell progenitors (MHC class II+, CD80(dim), CD86) prolong cardiac allograft survival in nonimmunosuppressed recipients," Transplantation, vol. 62, no. 5, pp. 659-665, 1996.

[92] M. B. Lutz, R. M. Suri, M. Niimi et al., "Immature dendritic cells generated with low doses of GM-CSF in the absence of IL-4 are maturation resistant and prolong allograft survival in vivo," European Journal of Immunology, vol. 30, pp. 1813-1822, 2000.

[93] P. J. O'Connell, W. Li, Z. Wang, S. M. Specht, A. J. Logar, and A. W. Thomson, "Immature and mature $\mathrm{CD} 8 \alpha^{+}$dendritic cells prolong the survival of vascularized heart allografts," Journal of Immunology, vol. 168, no. 1, pp. 143-154, 2002.

[94] D. L. Roelen, D. H. Schuurhuis, D. E. M. Van Den Boogaardt et al., "Prolongation of skin graft survival by modulation of the alloimmune response with alternatively activated dendritic cells," Transplantation, vol. 76, no. 11, pp. 1608-1615, 2003.

[95] K. Sato, N. Yamashita, N. Yamashita, M. Baba, and T. Matsuyama, "Regulatory dendritic cells protect mice from murine acute graft-versus-host disease and leukemia relapse," Immunity, vol. 18, no. 3, pp. 367-379, 2003.

[96] H. Pêche, B. Trinité, B. Martinet, and M. C. Cuturi, "Prolongation of heart allograft survival by immature dendritic cells generated from recipient type bone marrow progenitors," American Journal of Transplantation, vol. 5, no. 2, pp. 255-267, 2005.

[97] C. Caux, C. Dezutter-Dambuyant, D. Schmit, and J. Banchereau, "GM-CSF and TNF- $\alpha$ cooperate in the generation of dendritic Langerhans cells," Nature, vol. 360, no. 6401, pp. 258-261, 1992.

[98] M. Arpinati, C. L. Green, S. Heimfeld, J. E. Heuser, and C. Anasetti, "Granulocyte-colony stimulating factor mobilizes $\mathrm{T}$ helper 2-inducing dendritic cells," Blood, vol. 95, no. 8, pp. 2484-2490, 2000.

[99] K. Y. Vermaelen, I. Carro-Muino, B. N. Lambrecht, and R. A. Pauwels, "Specific migratory dendritic cells rapidly transport antigen from the airways to the thoracic lymph nodes," Journal of Experimental Medicine, vol. 193, no. 1, pp. 51-60, 2001.

[100] I. Apostolou and H. Von Boehmer, "In vivo instruction of suppressor commitment in naive T cells," Journal of Experimental Medicine, vol. 199, no. 10, pp. 1401-1408, 2004.

[101] M. Ostroukhova, C. Seguin-Devaux, T. B. Oriss et al., "Tolerance induced by inhaled antigen involves $\mathrm{CD}^{+} \mathrm{T}$ cells expressing membrane-bound TGF- $\beta$ and FOXP3," Journal of Clinical Investigation, vol. 114, no. 1, pp. 28-38, 2004.

[102] H. J. De Heer, H. Hammad, T. Soullié et al., "Essential role of lung plasmacytoid dendritic cells in preventing asthmatic reactions to harmless inhaled antigen," Journal of Experimental Medicine, vol. 200, no. 1, pp. 89-98, 2004.

[103] K. Kretschmer, I. Apostolou, D. Hawiger, K. Khazaie, M. C. Nussenzweig, and H. von Boehmer, "Inducing and expanding regulatory $\mathrm{T}$ cell populations by foreign antigen," Nature Immunology, vol. 6, no. 12, pp. 1219-1227, 2005.

[104] S. Yamazaki, K. Inaba, K. V. Tarbell, and R. M. Steinman, "Dendritic cells expand antigen-specific Foxp3+CD $25^{+} \mathrm{CD} 4{ }^{+}$ regulatory $\mathrm{T}$ cells including suppressors of alloreactivity," Immunological Reviews, vol. 212, pp. 314-329, 2006.

[105] N. M. Tsuji and A. Kosaka, "Oral tolerance: intestinal homeostasis and antigen-specific regulatory T cells," Trends in Immunology, vol. 29, no. 11, pp. 532-540, 2008.

[106] B. N. Lambrecht and H. Hammad, "Biology of lung dendritic cells at the origin of asthma," Immunity, vol. 31, no. 3, pp. 412424, 2009.

[107] T. Birnberg, L. Bar-On, A. Sapoznikov et al., "Lack of conventional dendritic cells is compatible with normal development and $\mathrm{T}$ cell homeostasis, but causes myeloid proliferative syndrome," Immunity, vol. 29, no. 6, pp. 986-997, 2008.

[108] G. Darrasse-Jèze, S. Deroubaix, H. Mouquet et al., "Feedback control of regulatory $\mathrm{T}$ cell homeostasis by dendritic cells in vivo," Journal of Experimental Medicine, vol. 206, no. 9, pp. 18531862, 2009.

[109] S. Paust and H. Cantor, "Regulatory T cells and autoimmune disease," Immunological Reviews, vol. 204, pp. 195-207, 2005.

[110] Q. Tang and J. A. Bluestone, “The Foxp3+ regulatory T cell: a jack of all trades, master of regulation," Nature Immunology, vol. 9, no. 3, pp. 239-244, 2008.

[111] D. A. A. Vignali, L. W. Collison, and C. J. Workman, "How regulatory T cells work," Nature Reviews Immunology, vol. 8, no. 7, pp. 523-532, 2008.

[112] M. A. Travis, B. Reizis, A. C. Melton et al., "Loss of integrin $\alpha v \beta 8$ on dendritic cells causes autoimmunity and colitis in mice," Nature, vol. 449, no. 7160, pp. 361-365, 2007.

[113] Y. Laouar, T. Town, D. Jeng et al., "TGF- $\beta$ signaling in dendritic cells is a prerequisite for the control of autoimmune encephalomyelitis," Proceedings of the National Academy of Sciences of the United States of America, vol. 105, no. 31, pp. 10865-10870, 2008.

[114] J. A. Bluestone and A. K. Abbas, "Natural versus adaptive regulatory T cells," Nature Reviews Immunology, vol. 3, no. 3, pp. 253-257, 2003.

[115] C.-W. J. Lio and C.-S. Hsieh, "A two-step process for thymic regulatory T cell development," Immunity, vol. 28, no. 1, pp. 100111, 2008.

[116] J. E. Mold, J. Michaëlsson, T. D. Burt et al., "Maternal alloantigens promote the development of tolerogenic fetal regulatory $\mathrm{T}$ cells in utero," Science, vol. 322, no. 5907, pp. 1562-1565, 2008. 
[117] J. M. Kim and A. Rudensky, "The role of the transcription factor Foxp3 in the development of regulatory T cells," Immunological Reviews, vol. 212, pp. 86-98, 2006.

[118] M. V. Dhodapkar, R. M. Steinman, J. Krasovsky, C. Munz, and N. Bhardwaj, "Antigen-specific inhibition of effector T cell function in humans after injection of immature dendritic cells," Journal of Experimental Medicine, vol. 193, no. 2, pp. 233-238, 2001.

[119] C. Reis E Sousa, "Dendritic cells in a mature age," Nature Reviews Immunology, vol. 6, no. 6, pp. 476-483, 2006.

[120] R. Tisch, "Immunogenic versus tolerogenic dendritic cells: a matter of maturation," International Reviews of Immunology, vol. 29, no. 2, pp. 111-118, 2010.

[121] L. Ohl, M. Mohaupt, N. Czeloth et al., "CCR7 governs skin dendritic cell migration under inflammatory and steady-state conditions," Immunity, vol. 21, no. 2, pp. 279-288, 2004.

[122] G. Hintzen, L. Ohl, M.-L. Del Rio et al., "Induction of tolerance to innocuous inhaled antigen relies on a CCR7-dependent dendritic cell-mediated antigen transport to the bronchial lymph node," Journal of Immunology, vol. 177, no. 10, pp. 73467354, 2006.

[123] M. H. Jang, N. Sougawa, T. Tanaka et al., "CCR7 is critically important for migration of dendritic cells in intestinal lamina propria to mesenteric lymph nodes," Journal of Immunology, vol. 176, no. 2, pp. 803-810, 2006.

[124] T. Worbs, U. Bode, S. Yan et al., "Oral tolerance originates in the intestinal immune system and relies on antigen carriage by dendritic cells," Journal of Experimental Medicine, vol. 203, no. 3, pp. 519-527, 2006.

[125] R. Förster, A. C. Davalos-Misslitz, and A. Rot, "CCR7 and its ligands: balancing immunity and tolerance," Nature Reviews Immunology, vol. 8, no. 5, pp. 362-371, 2008.

[126] M. Cella, F. Facchetti, A. Lanzavecchia, and M. Colonna, "Plasmacytoid dendritic cells activated by influenza virus and CD40L drive a potent TH1 polarization," Nature Immunology, vol. 1, no. 4, pp. 305-310, 2000.

[127] H. Hadeiba, T. Sato, A. Habtezion, C. Oderup, J. Pan, and E. C. Butcher, "CCR9 expression defines tolerogenic plasmacytoid dendritic cells able to suppress acute graft-versus-host disease," Nature Immunology, vol. 9, no. 11, pp. 1253-1260, 2008.

[128] D. Tokita, G. V. Mazariegos, A. F. Zahorchak et al., "High PD-L1/CD86 ratio on plasmacytoid dendritic cells correlates with elevated T-regulatory cells in liver transplant tolerance," Transplantation, vol. 85, no. 3, pp. 369-377, 2008.

[129] M. Kool, M. Van Nimwegen, M. A. M. Willart et al., "An antiinflammatory role for plasmacytoid dendritic cells in allergic airway inflammation," Journal of Immunology, vol. 183, no. 2, pp. 1074-1082, 2009.

[130] Q. Tang and J. A. Bluestone, "Plasmacytoid DCs and Treg cells: casual acquaintance or monogamous relationship?" Nature Immunology, vol. 7, no. 6, pp. 551-553, 2006.

[131] J. C. Ochando, C. Homma, Y. Yang et al., "Alloantigenpresenting plasmacytoid dendritic cells mediate tolerance to vascularized grafts," Nature Immunology, vol. 7, no. 6, pp. 652$662,2006$.

[132] M. Abe, Z. Wang, A. De Creus, and A. W. Thomson, "Plasmacytoid dendritic cell precursors induce allogeneic T-cell hyporesponsiveness and prolong heart graft survival," American Journal of Transplantation, vol. 5, no. 8, pp. 1808-1819, 2005.

[133] M. Gilliet and Y.-J. Liu, "Generation of human CD8 T regulatory cells by CD40 ligand-activated plasmacytoid dendritic cells,"
Journal of Experimental Medicine, vol. 195, no. 6, pp. 695-704, 2002.

[134] A. I. Proietto, S. Van Dommelen, P. Zhou et al., "Dendritic cells in the thymus contribute to T-regulatory cell induction," Proceedings of the National Academy of Sciences of the United States of America, vol. 105, no. 50, pp. 19869-19874, 2008.

[135] N. Watanabe, Y.-H. Wang, H. K. Lee et al., "Hassall's corpuscles instruct dendritic cells to induce $\mathrm{CD} 4{ }^{+} \mathrm{CD} 25^{+}$regulatory T cells in human thymus," Nature, vol. 436, no. 7054, pp. 1181-1185, 2005.

[136] G. Beriou, A. Moreau, and M. C. Cuturi, "Tolerogenic dendritic cells: applications for solid organ transplantation," Current Opinion in Organ Transplantation, vol. 17, no. 1, pp. 42-47, 2012.

[137] A. W. Thomson, “Tolerogenic dendritic cells: all present and correct?" American Journal of Transplantation, vol. 10, no. 2, pp. 214-219, 2010.

[138] P. T. H. Coates, B. L. Colvin, H. Hackstein, and A. W. Thomson, "Manipulation of dendritic cells as an approach to improved outcomes in transplantation," Expert Reviews in Molecular Medicine, vol. 4, no. 3, pp. 1-21, 2002.

[139] P. T. H. Coates, B. L. Colvin, K. Kaneko, T. Taner, and A. W. Thomson, "Pharmacologic, biologic, and genetic engineering approaches to potentiation of donor-derived dendritic cell tolerogenicity," Transplantation, vol. 75, no. 9, pp. 32S-36S, 2003.

[140] H. Hackstein and A. W. Thomson, "Dendritic cells: emerging pharmacological targets of immunosuppressive drugs," Nature Reviews Immunology, vol. 4, no. 1, pp. 24-34, 2004.

[141] A. H. Enk, "Dendritic cells in tolerance induction," Immunology Letters, vol. 99, no. 1, pp. 8-11, 2005.

[142] K. R. McCurry, B. L. Colvin, A. F. Zahorchak, and A. W. Thomson, "Regulatory dendritic cell therapy in organ transplantation," Transplant International, vol. 19, no. 7, pp. 525-538, 2006.

[143] R. Schwartz and W. Dameshek, "Drug-induced immunological tolerance," Nature, vol. 183, no. 4676, pp. 1682-1683, 1959.

[144] M. Moser, T. De Smedt, T. Sornasse et al., "Glucocorticoids down-regulate dendritic cell function in vitro and in vivo," European Journal of Immunology, vol. 25, no. 10, pp. 2818-2824, 1995.

[145] L. Piemonti, P. Monti, P. Allavena et al., "Glucocorticoids affect human dendritic cell differentiation and maturation," Journal of Immunology, vol. 162, no. 11, pp. 6473-6481, 1999.

[146] N. Vanderheyde, V. Verhasselt, M. Goldman, and F. Willems, "Inhibition of human dendritic cell functions by methylprednisolone," Transplantation, vol. 67, no. 10, pp. 1342-1347, 1999.

[147] M. K. Matyszak, S. Citterio, and M. Rescigno, "Differential effects of corticosteroids during different stages of dendritic cell maturation," European Journal of Immunology, vol. 30, pp. 1233$1242,2000$.

[148] A. M. Woltman, J. W. de Fijter, S. W. Kamerling, L. C. Paul, M. R. Daha, and C. van Kooten, "The effect of calcineurin inhibitors and corticosteroids on the differentiation of human dendritic cells," European Journal of Immunology, vol. 30, no. 7, pp. 1807$1812,2000$.

[149] A. E. Pedersen, E. G. W. Schmidt, M. Gad, S. S. Poulsen, and M. H. Claesson, "Dexamethasone $/ 1 \alpha$-25-dihydroxyvitamin D3-treated dendritic cells suppress colitis in the SCID T-cell transfer model," Immunology, vol. 127, no. 3, pp. 354-364, 2009.

[150] M. Abe and A. W. Thomson, "Dexamethasone preferentially suppresses plasmacytoid dendritic cell differentiation and 
enhances their apoptotic death," Clinical Immunology, vol. 118, no. 2-3, pp. 300-306, 2006.

[151] L. Piemonti, P. Monti, M. Sironi et al., "Vitamin D3 affects differentiation, maturation, and function of human monocytederived dendritic cells," Journal of Immunology, vol. 164, no. 9, pp. 4443-4451, 2000.

[152] M. D. Griffin, W. H. Lutz, V. A. Phan, L. A. Bachman, D. J. McKean, and R. Kumar, "Potent inhibition of dendritic cell differentiation and maturation by vitamin D analogs," Biochemical and Biophysical Research Communications, vol. 270, no. 3, pp. 701-708, 2000.

[153] D. Raïch-Regué, L. Grau-Lopez, M. Naranjo-Gomez et al., "Stable antigen-specific T-cell hyporesponsiveness induced by tolerogenic dendritic cells from multiple sclerosis patients," European Journal of Immunology, vol. 42, no. 3, pp. 771-782, 2012.

[154] R. A. Harry, A. E. Anderson, J. D. Isaacs, and C. M. U. Hilkens, "Generation and characterisation of therapeutic tolerogenic dendritic cells for rheumatoid arthritis," Annals of the Rheumatic Diseases, vol. 69, no. 11, pp. 2042-2050, 2010.

[155] A. E. Anderson, B. L. Sayers, M. A. Haniffa et al., "Differential regulation of naïve and memory $\mathrm{CD} 4^{+} \mathrm{T}$ cells by alternatively activated dendritic cells," Journal of Leukocyte Biology, vol. 84, no. 1, pp. 124-133, 2008.

[156] A. E. Anderson, D. J. Swan, B. L. Sayers et al., "LPS activation is required for migratory activity and antigen presentation by tolerogenic dendritic cells," Journal of Leukocyte Biology, vol. 85, no. 2, pp. 243-250, 2009.

[157] K. Steinbrink, M. Wölfl, H. Jonuleit, J. Knop, and A. H. Enk, "Induction of tolerance by IL-10-treated dendritic cells," Journal of Immunology, vol. 159, no. 10, pp. 4772-4780, 1997.

[158] C. Buelens, F. Willems, A. Delvaux et al., "Interleukin-10 differentially regulates B7-1 (CD80) and B7-2 (CD86) expression on human peripheral blood dendritic cells," European Journal of Immunology, vol. 25, no. 9, pp. 2668-2672, 1995.

[159] C. Buelens, V. Verhasselt, D. De Groote, K. Thielemans, M. Goldman, and F. Willems, "Human dendritic cell responses to lipopolysaccharide and CD40 ligation are differentially regulated by interleukin-10," European Journal of Immunology, vol. 27, no. 8, pp. 1848-1852, 1997.

[160] K. Steinbrink, H. Jonuleit, G. Müller, G. Schuler, J. Knop, and A. H. Enk, "Interleukin-10-treated human dendritic cells induce a melanoma-antigen- specific anergy in $\mathrm{CD}^{+} \mathrm{T}$ cells resulting in a failure to lyse tumor cells," Blood, vol. 93, no. 5, pp. 1634-1642, 1999.

[161] K. Steinbrink, E. Graulich, S. Kubsch, J. Knop, and A. H. Enk, "CD4 ${ }^{+}$and $\mathrm{CD}^{+}$anergic $\mathrm{T}$ cells induced by interleukin-10treated human dendritic cells display antigen-specific suppressor activity," Blood, vol. 99, no. 7, pp. 2468-2476, 2002.

[162] A. F. Zahorchak, L. S. Kean, D. Tokita et al., "Infusion of stably immature monocyte-derived dendritic cells plus CTLA4Ig modulates alloimmune reactivity in rhesus macaques," Transplantation, vol. 84, no. 2, pp. 196-206, 2007.

[163] S. Gregori, D. Tomasoni, V. Pacciani et al., "Differentiation of type $1 \mathrm{~T}$ regulatory cells (Tr1) by tolerogenic DC-10 requires the IL-10-dependent ILT4/HLA-G pathway," Blood, vol. 116, no. 6, pp. 935-944, 2010.

[164] M. K. Levings, S. Gregori, E. Tresoldi, S. Cazzaniga, C. Bonini, and M. G. Roncarolo, "Differentiation of Tr1 cells by immature dendritic cells requires IL-10 but not $\mathrm{CD} 25^{+} \mathrm{CD} 4^{+} \mathrm{Tr}$ cells," Blood, vol. 105, no. 3, pp. 1162-1169, 2005.
[165] T. Takayama, A. E. Morelli, N. Onai et al., "Mammalian and viral IL-10 enhance C-C chemokine receptor 5 but down-regulate C$\mathrm{C}$ chemokine receptor 7 expression by myeloid dendritic cells: impact on chemotactic responses and in vivo homing ability," Journal of Immunology, vol. 166, no. 12, pp. 7136-7143, 2001.

[166] V. Sordi, G. Bianchi, C. Buracchi et al., "Differential effects of immunosuppressive drugs on chemokine receptor CCR7 in human monocyte-derived dendritic cells: selective upregulation by rapamycin," Transplantation, vol. 82, no. 6, pp. 826-834, 2006.

[167] Y.-R. Lee, I.-H. Yang, Y.-H. Lee et al., "Cyclosporin A and tacrolimus, but not rapamycin, inhibit $\mathrm{MHC}$-restricted antigen presentation pathways in dendritic cells," Blood, vol. 105, no. 10, pp. 3951-3955, 2005.

[168] H. Matsue, C. Yang, K. Matsue, D. Edelbaum, M. Mummert, and A. Takashima, "Contrasting impacts of immunosuppressive agents (rapamycin, FK506, cyclosporin A, and dexamethasone) on bidirectional dendritic cell-T cell interaction during antigen presentation," Journal of Immunology, vol. 169, no. 7, pp. 35553564, 2002.

[169] T. Chen, J. Guo, M. Yang et al., "Cyclosporin A impairs dendritic cell migration by regulating chemokine receptor expression and inhibiting cyclooxygenase-2 expression," Blood, vol. 103, no. 2, pp. 413-421, 2004.

[170] A. Mehling, S. Grabbe, M. Voskort, T. Schwarz, T. A. Luger, and S. Beissert, "Mycophenolate mofetil impairs the maturation and function of murine dendritic cells," Journal of Immunology, vol. 165, no. 5, pp. 2374-2381, 2000.

[171] R. Matasic, A. B. Dietz, and S. Vuk-Pavlovic, "Cyclooxygenaseindependent inhibition of dendritic cell maturation by aspirin," Immunology, vol. 101, no. 1, pp. 53-60, 2000.

[172] H. Hackstein, A. E. Morelli, A. T. Larregina et al., "Aspirin inhibits in vitro maturation and in vivo immunostimulatory function of murine myeloid dendritic cells," Journal of Immunology, vol. 166, no. 12, pp. 7053-7062, 2001.

[173] M. Buckland, C. B. Jago, H. Fazekasova et al., "Aspirin-treated human DCs up-regulate ILT-3 and induce hyporesponsiveness and regulatory activity in responder T cells," American Journal of Transplantation, vol. 6, no. 9, pp. 2046-2059, 2006.

[174] M. Buckland and G. Lombardi, "Aspirin and the induction of tolerance by dendritic cells," Handbook of Experimental Pharmacology, vol. 188, pp. 197-213, 2009.

[175] M. A. Tepper, S. G. Nadler, J. M. Esselstyn, and K. G. Sterbenz, "Deoxyspergualin inhibits $\kappa$ light chain expression in $70 \mathrm{Z} / 3$ pre-B cells by blocking lipopolysaccharide-induced NF- $\kappa$ b activation," Journal of Immunology, vol. 155, no. 5, pp. 2427-2436, 1995.

[176] M.-M. Tiao, L. Lu, R. Tao, L. Wang, J. J. Fung, and S. Qian, "Prolongation of cardiac allograft survival by systemic administration of immature recipient dendritic cells deficient in NF- $\kappa$ B activity," Annals of Surgery, vol. 241, no. 3, pp. 497-505, 2005.

[177] A. Hernandez, M. Burger, B. B. Blomberg et al., "Inhibition of NF- $\kappa \mathrm{B}$ during human dendritic cell differentiation generates anergy and regulatory $\mathrm{T}$-cell activity for one but not two human leukocyte antigen DR mismatches," Human Immunology, vol. 68, no. 9, pp. 715-729, 2007.

[178] W. Grotz, S. Siebig, M. Olschewski, C. W. Strey, and K. Peter, "Low-dose aspirin therapy is associated with improved allograft function and prolonged allograft survival after kidney transplantation," Transplantation, vol. 77, no. 12, pp. 1848-1853, 2004. 
[179] Z.-X. Zhang, L. Yang, K. J. Young, B. DuTemple, and L. Zhang, "Identification of a previously unknown antigen-specific regulatory $\mathrm{T}$ cell and its mechanism of suppression," Nature Medicine, vol. 6, no. 7, pp. 782-789, 2000.

[180] B. Sawitzki, C. I. Kingsley, V. Oliveira, M. Karim, M. Herber, and K. J. Wood, "IFN- $\gamma$ production by alloantigen-reactive regulatory $\mathrm{T}$ cells is important for their regulatory function in vivo," Journal of Experimental Medicine, vol. 201, no. 12, pp. 1925-1935, 2005.

[181] L. Zhang and A. W. Thomson, "New partners for tolerogenic dendritic cells," American Journal of Transplantation, vol. 11, no. 10, pp. 2003-2004, 2011.

[182] A. W. Thomson, H. R. Turnquist, and G. Raimondi, "Immunoregulatory functions of mTOR inhibition," Nature Reviews Immunology, vol. 9, no. 5, pp. 324-337, 2009.

[183] T. Weichhart, G. Costantino, M. Poglitsch et al., "The TSCmTOR signaling pathway regulates the innate inflammatory response," Immunity, vol. 29, no. 4, pp. 565-577, 2008.

[184] H. R. Turnquist, G. Raimondi, A. F. Zahorchak, R. T. Fischer, Z. Wang, and A. W. Thomson, "Rapamycin-conditioned dendritic cells are poor stimulators of allogeneic $\mathrm{CD} 4^{+} \mathrm{T}$ cells, but enrich for antigen-specific Foxp3+ $\mathrm{T}$ regulatory cells and promote organ transplant tolerance," Journal of Immunology, vol. 178, no. 11, pp. 7018-7031, 2007.

[185] H. R. Turnquist, T. L. Sumpter, A. Tsung et al., "IL-1 $\beta$-driven ST2L expression promotes maturation resistance in rapamycinconditioned dendritic cells," Journal of Immunology, vol. 181, no. 1, pp. 62-72, 2008.

[186] H. R. Turnquist, J. Cardinal, C. Macedo et al., "mTOR and GSK3 shape the $\mathrm{CD} 4^{+} \mathrm{T}$-cell stimulatory and differentiation capacity of myeloid DCs after exposure to LPS," Blood, vol. 115, no. 23, pp. 4758-4769, 2010.

[187] M. Naranjo-Gomez, D. Raïch-Regué, C. Oñate et al., "Comparative study of clinical grade human tolerogenic dendritic cells," Journal of Translational Medicine, vol. 9, article 89, 2011.

[188] T. Matsumoto, H. Hasegawa, S. Onishi, J. Ishizaki, K. Suemori, and M. Yasukawa, "Protein kinase C inhibitor generates stable human tolerogenic dendritic cells," Journal of Immunology, vol. 191, no. 5, pp. 2247-2257, 2013.

[189] A. Moreau, M. Hill, P. Thébault et al., "Tolerogenic dendritic cells actively inhibit $\mathrm{T}$ cells through heme oxygenase- 1 in rodents and in nonhuman primates," FASEB Journal, vol. 23, no. 9, pp. 3070-3077, 2009.

[190] S. Chitta, L. Santambrogio, and L. J. Stern, "GMCSF in the absence of other cytokines sustains human dendritic cell precursors with $\mathrm{T}$ cell regulatory activity and capacity to differentiate into functional dendritic cells," Immunology Letters, vol. 116, no. 1, pp. 41-54, 2008.

[191] L. Lu, W. Li, C. Zhong et al., "Increased apoptosis of immunoreactive host cells and augmented donor leukocyte chimerism, not sustained inhibition of B7 molecule expression are associated with prolonged cardiac allograft survival in mice preconditioned with immature donor dendritic cells plus anti-CD40L mAb," Transplantation, vol. 68, no. 6, pp. 747-757, 1999.

[192] Q. Wang, M. Zhang, G. Ding et al., "Anti-ICAM-1 antibody and CTLA-4Ig synergistically enhance immature dendritic cells to induce donor-specific immune tolerance in vivo," Immunology Letters, vol. 90, no. 1, pp. 33-42, 2003.

[193] Z. Wang, A. E. Morelli, H. Hackstein, K. Kaneko, and A. W. Thomson, "Marked inhibition of transplant vascular sclerosis by in vivo-mobilized donor dendritic cells and anti-CD154 mAb," Transplantation, vol. 76, no. 3, pp. 562-571, 2003.
[194] O. Azhipa, K. Kimizuka, A. Nakao et al., "Comparative analysis of the fate of donor dendritic cells and B cells and their influence on alloreactive $\mathrm{T}$ cell responses under tacrolimus immunosuppression," Clinical Immunology, vol. 114, no. 2, pp. 199-209, 2005.

[195] A. Imai, H. Sahara, Y. Tamura et al., "Inhibition of endogenous MHC class II-restricted antigen presentation by tacrolimus (FK506) via FKBP51," European Journal of Immunology, vol. 37, no. 7, pp. 1730-1738, 2007.

[196] C. Voigtländer, S. Rößner, E. Cierpka et al., "Dendritic cells matured with TNF can be further activated in vitro and after subcutaneous injection in vivo which converts their tolerogenicity into immunogenicity," Journal of Immunotherapy, vol. 29, no. 4, pp. 407-415, 2006.

[197] D.-S. Lim, M.-S. Kang, J.-A. Jeong, and Y.-S. Bae, "Semi-mature DC are immunogenic and not tolerogenic when inoculated at a high dose in collagen-induced arthritis mice," European Journal of Immunology, vol. 39, no. 5, pp. 1334-1343, 2009.

[198] A. E. Morelli, A. T. Larregina, R. W. Ganster et al., "Recombinant adenovirus induces maturation of dendritic cells via an NF$\kappa \mathrm{B}$-dependent pathway," Journal of Virology, vol. 74, no. 20, pp. 9617-9628, 2000.

[199] J.-M. Humbert and F. Halary, "Viral and non-viral methods to genetically modify Dendritic cells," Current Gene Therapy, vol. 12, no. 2, pp. 127-136, 2012.

[200] D. Rea, D. Laface, B. Hutchins et al., "Recombinant adenovirustransduced human dendritic cells engineered to secrete interleukin-10 (IL-10) suppress Th1-type responses while selectively activating IL-10-producing $\mathrm{CD} 4^{+}$T cells," Human Immunology, vol. 65, no. 11, pp. 1344-1355, 2004.

[201] P. T. H. Coates, R. Krishnan, S. Kireta, J. Johnston, and G. R. Russ, "Human myeloid dendritic cells transduced with an adenoviral interleukin-10 gene construct inhibit human skin graft rejection in humanized NOD-scid chimeric mice," Gene Therapy, vol. 8, no. 16, pp. 1224-1233, 2001.

[202] T. Takayama, H. Tahara, and A. W. Thomson, "Differential effects of myeloid dendritic cells retrovirally transduced to express mammalian or viral interleukin-10 on cytotoxic $\mathrm{T}$ lymphocyte and natural killer cell functions and resistance to tumor growth," Transplantation, vol. 71, no. 9, pp. 1334-1340, 2001.

[203] W.-C. Lee, C. Zhong, S. Qian et al., "Phenotype, function, and in vivo migration and survival of allogeneic dendritic cell progenitors genetically engineered to express TGF- $\beta$," Transplantation, vol. 66, no. 12, pp. 1810-1817, 1998.

[204] T. Takayama, K. Kaneko, A. E. Morelli, W. Li, H. Tahara, and A. W. Thomson, "Retroviral delivery of transforming growth factor- $\beta 1$ to myeloid dendritic cells: inhibition of T-cell priming ability and influence on allograft survival," Transplantation, vol. 74, no. 1, pp. 112-119, 2002.

[205] C. Asiedu, S. S. Dong, A. Pereboev et al., "Rhesus monocytederived dendritic cells modified to over-express TGF- $\beta 1$ exhibit potent veto activity," Transplantation, vol. 74, no. 5, pp. 629-637, 2002.

[206] S. Buonocore, S. Van Meirvenne, F.-X. Demoor et al., "Dendritic cells transduced with viral interleukin 10 or Fas ligand: no evidence for induction of allotolerance in vivo," Transplantation, vol. 73, no. 1, pp. S27-S30, 2002.

[207] W.-C. Lee, S. Qiani, Y. Wan et al., "Contrasting effects of myeloid dendritic cells transduced with an adenoviral vector encoding interleukin-10 on organ allograft and tumour rejection," Immunology, vol. 101, no. 2, pp. 233-241, 2000. 
[208] K. Kaneko, Z. Wang, S. H. Kim, A. E. Morelli, P. D. Robbins, and A. W. Thomson, "Dendritic cells genetically engineered to express IL-4 exhibit enhanced IL-12p70 production in response to CD40 ligation and accelerate organ allograft rejection," Gene Therapy, vol. 10, no. 2, pp. 143-152, 2003.

[209] J. Li, A. Meinhardt, M.-E. Roehrich et al., "Indoleamine 2,3dioxygenase gene transfer prolongs cardiac allograft survival," American Journal of Physiology, vol. 293, no. 6, pp. H3415H3423, 2007.

[210] C. A. Bonham, L. Peng, X. Liang et al., "Marked prolongation of cardiac allograft survival by dendritic cells genetically engineered with NF- $\kappa$ B oligodeoxyribonucleotide decoys and adenoviral vectors encoding CTLA4-Ig," Journal of Immunology, vol. 169, no. 6, pp. 3382-3391, 2002.

[211] L. Lu, A. Gambotto, W.-C. Lee et al., "Adenoviral delivery of CTLA4lg into myeloid dendritic cells promotes their in vitro tolerogenicity and survival in allogeneic recipients," Gene Therapy, vol. 6, no. 4, pp. 554-563, 1999.

[212] T. Takayama, A. E. Morelli, P. D. Robbins, H. Tahara, and A. W. Thomson, "Feasibility of CTLA4lg gene delivery and expression in vivo using retrovirally transduced myeloid dendritic cells that induce alloantigen-specific T cell anergy in vitro," Gene Therapy, vol. 7, no. 15, pp. 1265-1273, 2000.

[213] R. W. O’Rourke, S.-M. Kang, J. A. Lower et al., "A dendritic cell line genetically modified to express CTLA4-Ig as a means to prolong islet allograft survival," Transplantation, vol. 69, no. 7, pp. 1440-1446, 2000.

[214] W. Sun, Q. Wang, L. Zhang et al., "Blockade of CD40 pathway enhances the induction of immune tolerance by immature dendritic cells genetically modified to express cytotoxic $\mathrm{T}$ lymphocyte antigen 4 immunoglobulin," Transplantation, vol. 76, no. 9, pp. 1351-1359, 2003.

[215] H. Matsue, K. Matsue, M. Walters, K. Okumura, H. Yagita, and A. Takashima, "Induction of antigen-specific immunosuppression by CD95L cDNA- transfected 'killer' dendritic cells," Nature Medicine, vol. 5, no. 8, pp. 930-937, 1999.

[216] W.-P. Min, R. Gorczynski, X.-Y. Huang et al., "Dendritic cells genetically engineered to express Fas ligand induce donorspecific hyporesponsiveness and prolong allograft survival," Journal of Immunology, vol. 164, no. 1, pp. 161-167, 2000.

[217] S. Buonocore, F. Paulart, A. Le Moine et al., "Dendritic cells overexpressing CD95 (Fas) ligand elicit vigorous allospecific Tcell responses in vivo," Blood, vol. 101, no. 4, pp. 1469-1476, 2003.

[218] S. Buonocore, V. Flamand, N. Claessen, P. Heeringa, M. Goldman, and S. Florquin, "Dendritic cells overexpressing Fas-ligand induce pulmonary vasculitis in mice," Clinical and Experimental Immunology, vol. 137, no. 1, pp. 74-80, 2004.

[219] J. Machen, J. Harnaha, R. Lakomy, A. Styche, M. Trucco, and N. Giannoukakis, "Antisense oligonucleotides downregulating costimulation confer diabetes-preventive properties to nonobese diabetic mouse dendritic cells," Journal of Immunology, vol. 173, no. 7, pp. 4331-4341, 2004.

[220] X. Liang, L. Lu, Z. Chen et al., "Administration of dendritic cells transduced with antisense oligodeoxyribonucleotides targeting CD80 or CD86 prolongs allograft survival," Transplantation, vol. 76, no. 4, pp. 721-729, 2003.

[221] Q. Wang, Y. Liu, J. Wang et al., "Induction of allospecific tolerance by immature dendritic cells genetically modified to express soluble TNF receptor," Journal of Immunology, vol. 177, no. 4, pp. 2175-2185, 2006.

[222] K. R. Garrod, C. K. Chang, F.-C. Liu, T. V. Brennan, R. D. Foster, and S.-M. Kang, "Targeted lymphoid homing of dendritic cells is required for prolongation of allograft survival," Journal of Immunology, vol. 177, no. 2, pp. 863-868, 2006.

[223] M. J. Perone, S. Bertera, Z. S. Tawadrous et al., "Dendritic cells expressing transgenic galectin-1 delay onset of autoimmune diabetes in mice," Journal of Immunology, vol. 177, no. 8, pp. 5278-5289, 2006.

[224] D. Cooper, J. M. Ilarregui, S. A. Pesoa, D. O. Croci, M. Perretti, and G. A. Rabinovich, "Multiple functional targets of the immunoregulatory activity of Galectin-1. Control of immune cell trafficking, dendritic cell physiology, and T-cell fate," Methods in Enzymology, vol. 480, pp. 199-244, 2010.

[225] A. E. Morelli and A. W. Thomson, "Galectin-1, immune regulation and liver allograft survival," American Journal of Transplantation, vol. 13, no. 3, pp. 535-536, 2013.

[226] J. M. Ilarregui, D. O. Croci, G. A. Bianco et al., "Tolerogenic signals delivered by dendritic cells to T cells through a galectin1-driven immunoregulatory circuit involving interleukin 27 and interleukin 10," Nature Immunology, vol. 10, no. 9, pp. 981-991, 2009.

[227] P.-L. Kuo, J.-Y. Hung, S.-K. Huang et al., "Lung cancer-derived galectin-1 mediates dendritic cell anergy through inhibitor of DNA binding 3/IL-10 signaling pathway," Journal of Immunology, vol. 186, no. 3, pp. 1521-1530, 2011.

[228] A. Mobergslien and M. Sioud, "Galectin-1 and -3 gene silencing in immature and mature dendritic cells enhances $\mathrm{T}$ cell activation and interferon- $\gamma$ production," Journal of Leukocyte Biology, vol. 91, no. 3, pp. 461-467, 2012.

[229] Y. Ye, S. Yan, G. Jiang et al., "Galectin-1 prolongs survival of mouse liver allografts from Flt3L-pretreated donors," American Journal of Transplantation, vol. 13, no. 3, pp. 569-579, 2013.

[230] A. Moreau, A. Noble, K. Ratnasothy et al., "Absence of Galectin1 accelerates $\mathrm{CD}^{+} \mathrm{T}$ cell-mediated graft rejection," European Journal of Immunology, vol. 42, no. 11, pp. 2881-2888, 2012.

[231] A. E. Morelli, "The immune regulatory effect of apoptotic cells and exosomes on dendritic cells: its impact on transplantation," American Journal of Transplantation, vol. 6, no. 2, pp. 254-261, 2006.

[232] A. E. Morelli and A. T. Larregina, "Apoptotic cell-based therapies against transplant rejection: role of recipient's dendritic cells," Apoptosis, vol. 15, no. 9, pp. 1083-1097, 2010.

[233] T. H. Lee, E. D’Asti, N. Magnus, K. Al-Nedawi, B. Meehan, and J. Rak, "Microvesicles as mediators of intercellular communication in cancer-the emerging science of cellular 'debris," Seminars in Immunopathology, vol. 33, no. 5, pp. 455-467, 2011.

[234] Z. Wang, W. J. Shufesky, A. Montecalvo, S. J. Divito, A. T. Larregina, and A. E. Morelli, "In situ-targeting of dendritic cells with donor-derived apoptopic cells restrains indirect allorecognition and ameliorates allograft vasculopathy," PLOS ONE, vol. 4, no. 3, Article ID e4940, 2009.

[235] M. Garrovillo, A. Ali, H. A. Depaz et al., "Induction of transplant tolerance with immunodominant allopeptide-pulsed host lymphoid and myeloid dendritic cells," American Journal of Transplantation, vol. 1, no. 2, pp. 129-137, 2001.

[236] T. Taner, H. Hackstein, Z. Wang, A. E. Morelli, and A. W. Thomson, "Rapamycin-treated, alloantigen-pulsed host dendritic cells induce Ag-specific T cell regulation and prolong graft survival," American Journal of Transplantation, vol. 5, no. 2, pp. 228-236, 2005.

[237] P. Correale, G. Campoccia, K. Y. Tsang et al., "Recruitment of dendritic cells and enhanced antigen-specific immune reactivity in cancer patients treated with hr-GM-CSF (Molgramostim) 
and hr-IL-2: results from a phase Ib clinical trial," European Journal of Cancer, vol. 37, no. 7, pp. 892-902, 2001.

[238] B. G. Redman, A. E. C. Alfred E. Chang, J. W. Joel Whitfield et al., "Phase Ib trial assessing autologous, tumor-pulsed dendritic cells as a vaccine administered with or without IL-2 in patients with metastatic melanoma," Journal of Immunotherapy, vol. 31, no. 6, pp. 591-598, 2008.

[239] M. V. Dhodapkar and R. M. Steinman, "Antigen-bearing immature dendritic cells induce peptide-specific $\mathrm{CD}^{+}$regulatory $\mathrm{T}$ cells in vivo in humans," Blood, vol. 100, no. 1, pp. 174-177, 2002.

[240] R. Thomas, S. Street, N. Ramnoruth et al., "Safety and preliminary evidence of efficacy in a phase I clinical trial of autologous tolerising dendritic cells exposed to citrullinated peptides (Rheumavax) in patients with rheumatoid arthritis," Annals of the Rheumatic Diseases, vol. 70, supplement 3, article 169, 2011.

[241] A. Moreau, E. Varey, G. Bériou et al., “Tolerogenic dendritic cells and negative vaccination in transplantation: from rodents to clinical trials," Frontiers in Immunology, vol. 3, article 218, 2012.

[242] P. M. Emmer, J. Van Der Vlag, G. J. Adema, and L. B. Hilbrands, "Dendritic cells activated by lipopolysaccharide after dexamethasone treatment induce donor-specific allograft hyporesponsiveness," Transplantation, vol. 81, no. 10, pp. 14511459, 2006.

[243] G. Yu, X. Xu, D. V. Minh, E. D. Kilpatrick, and C. L. Xian, "NK cells promote transplant tolerance by killing donor antigenpresenting cells," Journal of Experimental Medicine, vol. 203, no. 8, pp. 1851-1858, 2006. 


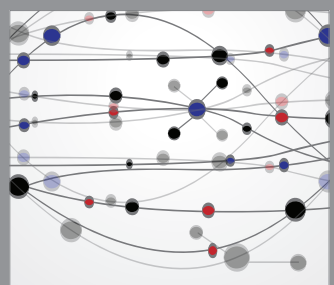

The Scientific World Journal
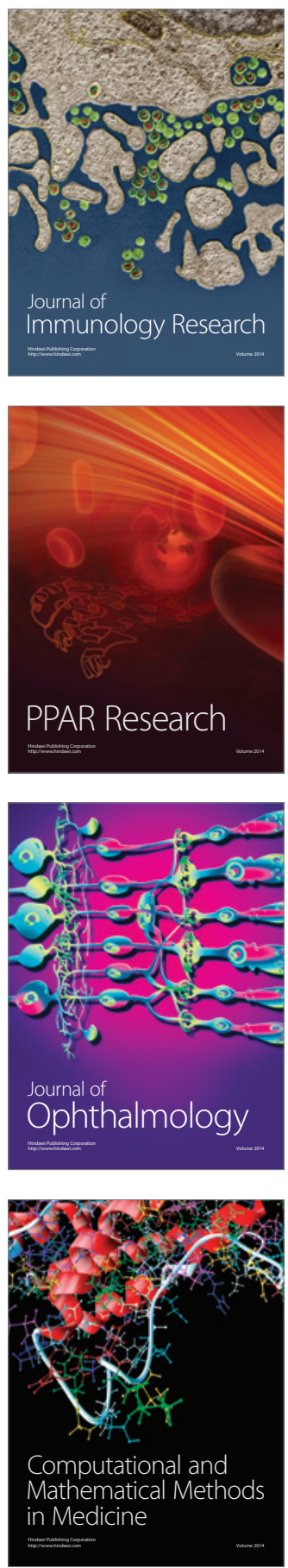

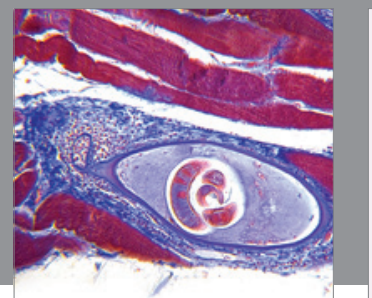

Gastroenterology

Research and Practice
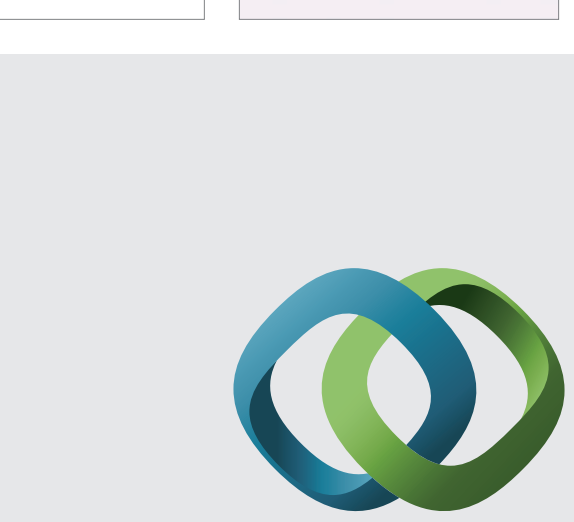

\section{Hindawi}

Submit your manuscripts at

http://www.hindawi.com
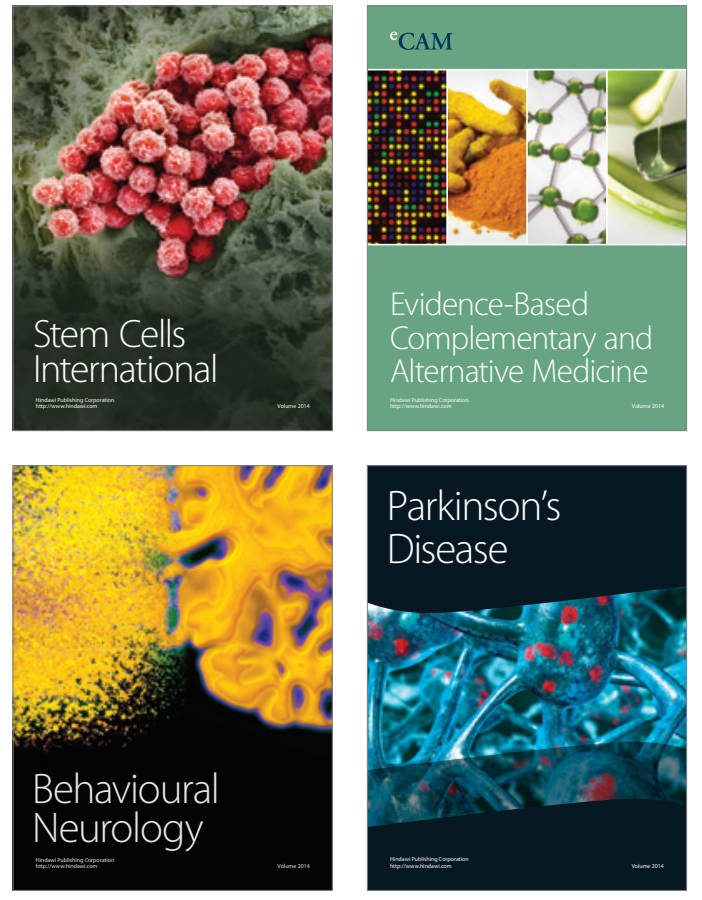
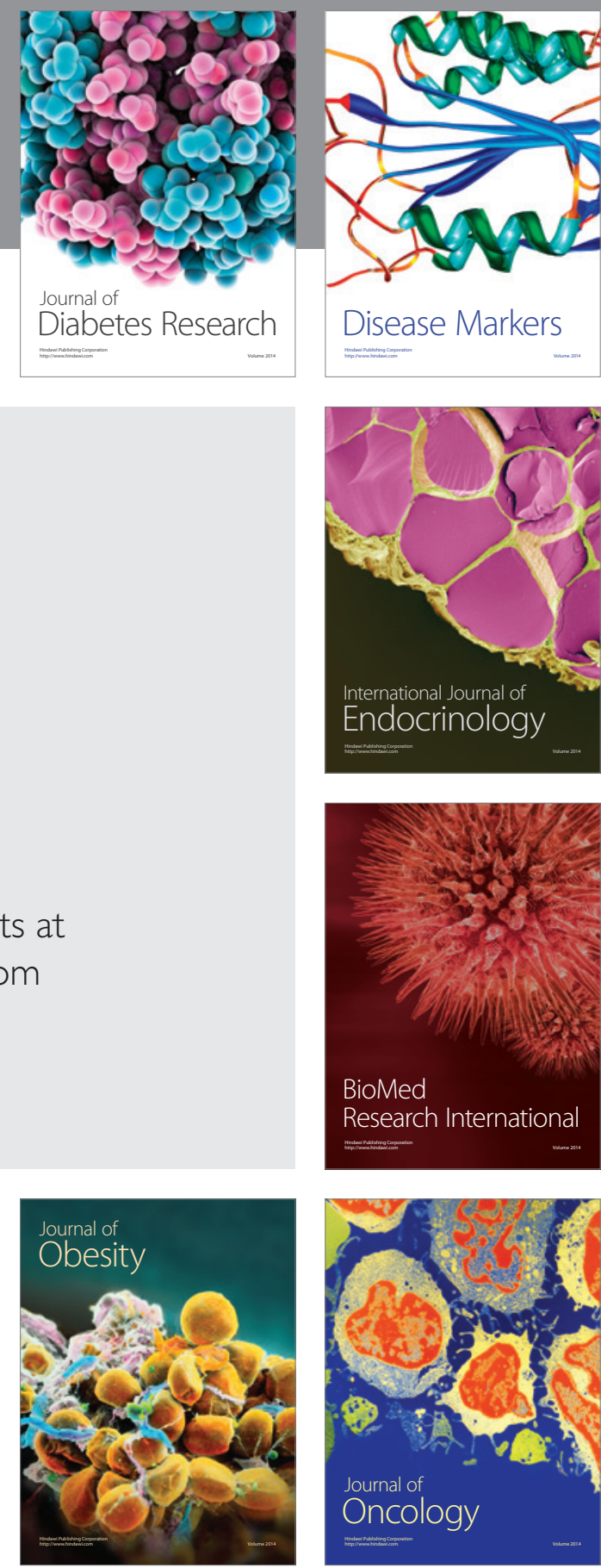

Disease Markers
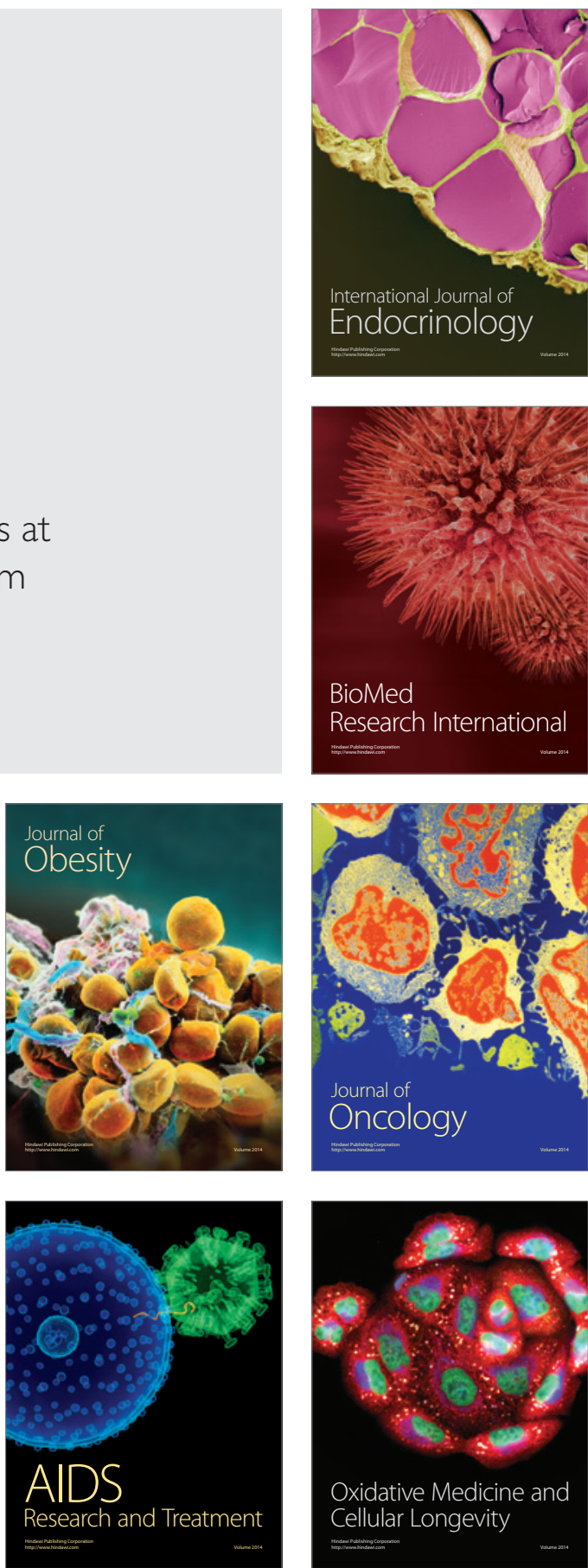